\title{
Carbon deposition on Ni/YSZ anode SOFC for direct methane steam reforming
}

Haiyang Li

hl0025@mix.wvu.edu

Follow this and additional works at: https://researchrepository.wvu.edu/etd

Part of the Ceramic Materials Commons

\section{Recommended Citation}

$\mathrm{Li}$, Haiyang, "Carbon deposition on Ni/YSZ anode SOFC for direct methane steam reforming" (2019). Graduate Theses, Dissertations, and Problem Reports. 4070.

https://researchrepository.wvu.edu/etd/4070

This Problem/Project Report is protected by copyright and/or related rights. It has been brought to you by the The Research Repository @WVU with permission from the rights-holder(s). You are free to use this Problem/Project Report in any way that is permitted by the copyright and related rights legislation that applies to your use. For other uses you must obtain permission from the rights-holder(s) directly, unless additional rights are indicated by a Creative Commons license in the record and/ or on the work itself. This Problem/Project Report has been accepted for inclusion in WVU Graduate Theses, Dissertations, and Problem Reports collection by an authorized administrator of The Research Repository @ WVU. For more information, please contact researchrepository@mail.wvu.edu. 
Carbon deposition on Ni-YSZ anode SOFC for direct methane steam reforming

\author{
Haiyang Li
}

Problem report submitted to the Benjamin M. Statler College of

Engineering and Mineral Resources at West Virginia University

in partial fulfillment of the requirements for the degree of Master in

Department of Mechanical \& Aerospace Engineering

\author{
Xingbo Liu, Ph.D., Chair \\ Terence Musho,Ph.D. \\ Wenyuan Li, Ph.D. \\ Department of Mechanical \& \\ Aerospace Engineering
}

Morgantown, West Virginia

2019

Keywords: SOFC, hydrocarbon reforming, carbon deposition

Copyright 2019 Haiyang Li 


\section{ABSTRACT \\ Carbon deposition on Ni-YSZ anode SOFC for direct methane steam reforming}

\section{Haiyang Li}

Solid Oxide Fuel Cells (SOFCs) are electrochemical devices that produce electricity directly from oxidizing fuels. Compared to direct combustion of hydrogen to generate power, it has a big advantage in aspects from efficiency and safety when using hydrogen as the fuel of SOFCs. Nowadays, about $50 \%$ of the hydrogen of world demand is derived from the natural gas. Hydrocarbon reforming is one of the conventional methods to convert nature gas into hydrogen. While, considering the difficulty in storage and transportation of hydrogen, we can utilize the supporting materials on the anode side of SOFCs as catalyst to generate hydrogen via hydrocarbon reforming process and pour the hydrogen as fuel into the SOFC system. Among many kinds of anode materials that have a good catalytic reforming and electrochemical reactivity, $\mathrm{Ni} / \mathrm{YSZ}$ is the most commonly used because of its cost-effective and well suitable for anode-supported fuel cell design requirements. While there are also some drawbacks, the biggest one is the performance degradation of fuel cell caused by solid carbon formation on the surface of the Ni/YSZ anode cermet, which may block gas diffusion tunnel. Moreover, the accumulation of carbon on catalysts can crack the cell.

In the present report, methane steam reforming and carbon deposition on Ni catalyst from the thermodynamic and kinetic views are discussed. The process of carbon deposition on Ni catalyst is also described. In order to face the challenge, some measures have been taken to suppress the effect including optimizing system parameters, addition of other metal elements and synthesizing smaller Ni particle catalyst. In the future, a lot of work should be done on adjusting catalyst compositions, feed compositions, and reaction conditions, especially on developing new materials that fit the system perfectly. For the application in SOFC system, it is reported to have less carbon deposition by adjusting the current density of the cell. More efforts are still to be made from the system aspect. 


\section{Table of Contents}

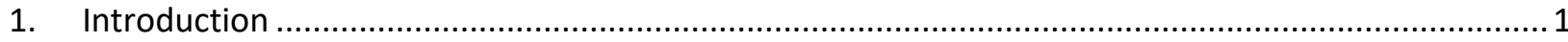

2. Carbon deposition and its mechanism on Ni-YSZ catalyst for methane steam reforming .................6

2.1 Thermodynamic calculations and experiments of carbon deposition for methane steam

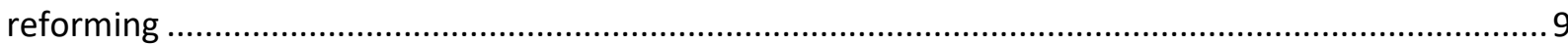

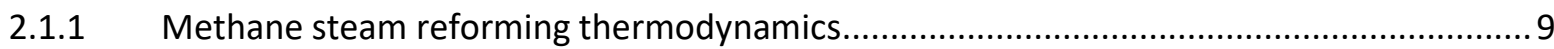

2.1.2 Thermodynamics of carbon deposition for methane steam reforming ..........................15

2.2 Kinetics of carbon deposition on Ni-YSZ catalyst...................................................................22

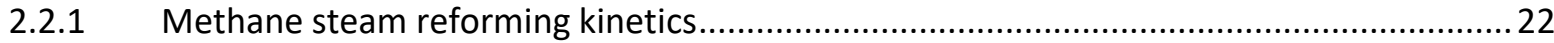

2.2.2 Kinetics of carbon deposition for methane steam reforming …....................................24

2.3 Description of carbon deposition process on Ni particle ...................................................28

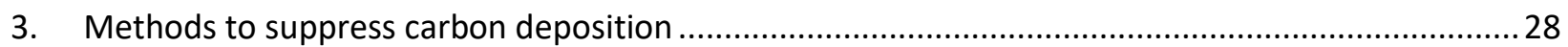

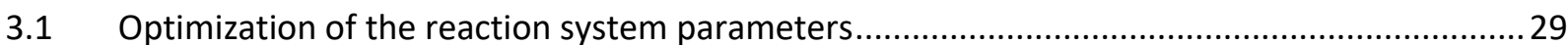

3.2 Metal elements or rare earth metal oxide addition ................................................................ 30

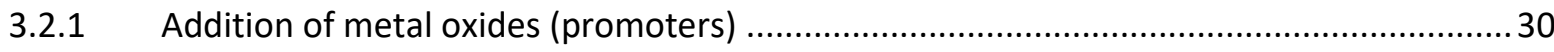

3.2.2 Alloying effect by addition of other metal elements ...................................................33

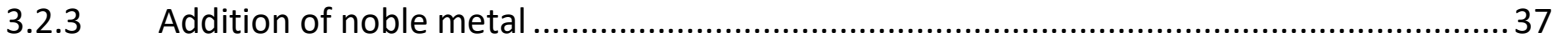

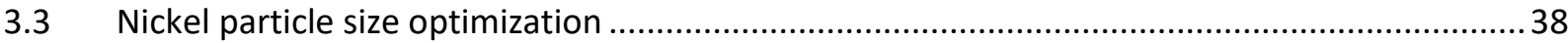

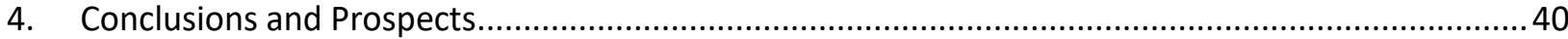

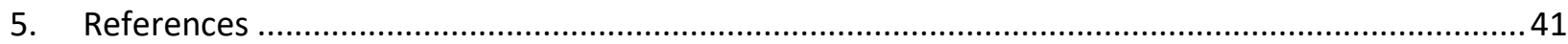




\section{Carbon deposition on Ni-YSZ anode SOFC for direct methane}

\section{steam reforming}

\section{Introduction}

Hydrogen is a perfect fuel gas for our human beings when we are facing greenhouse effect and try to avoid further temperature rise in our planet because of its environmental-friendly production after oxidation. About $50 \%$ of the hydrogen for world demand is derived from the natural gas. Hydrogen can be obtained from many resources including nuclear power, natural gas, coal, biomass and other renewable sources[1]. Overall, there are three conventional methods to generate hydrogen from natural gas nowadays, including hydrocarbon reforming, partial oxidation and auto-thermal reforming [2]. Methane is an important fuel source which we can get from seabed as methane hydrate and it is reported to be quite abundant that can support human beings for a long time. Because of the increase hydrogen demand and the importance of syngas production, methane reforming, including steam reforming and dry reforming, will be much more important in fields related to hydrogen economy [3].

In these two kinds of reforming reaction, methane dry reforming can consume $\mathrm{CO}_{2}$ which can reduce the greenhouse effect and make a contribution to the environment. However, methane dry reforming is reported to be inefficient because of the water-gas shift (WGS) reaction at 973K or higher temperature,

where is the temperature range for the typical operation of fuel cells. While methane steam reforming can still produce great amount of hydrogen in such circumstances. Moreover, a stable conversion rate of hydrogen generated by methane steam reforming is also at a very high level for higher pressure[4]. Besides the turnover rate difference between these two reactions, the side product is another big issue we have to take into consideration. For methane dry reforming, carbon is inevitable in production because the high atom percentage in the reactants and carbon is especially harmful to fuel cell system. Carbon like graphite 
or other forms has high hardness which can crack the pallet. While methane steam reforming reaction can efficiently reduce the effect. So methane steam reforming is overall a much more promising way to better use the natural gas which we can get directly from seabed or via fossil fuel decomposition.

The reaction of methane steam reforming is given in following reaction equation:

$$
\mathrm{CH}_{4}+\mathrm{H}_{2} \mathrm{O} \leftrightarrow \mathrm{CO}+3 \mathrm{H}_{2} \quad \Delta H_{298}^{0}=206 \mathrm{KJ} / \mathrm{mol}(1)
$$

Methane steam reforming is an endothermic reaction which requires very high temperature $\left(700^{\circ} \mathrm{C}\right.$ $-900^{\circ} \mathrm{C}$ ) and catalysts are needed to realize the reaction. Catalysts like $\mathrm{Ni}, \mathrm{Pt}$ and rare earth elements are great candidates for the reaction because they all have a high catalytic efficiency on methane steam reforming. The details of these catalysts will be discussed in following sections.
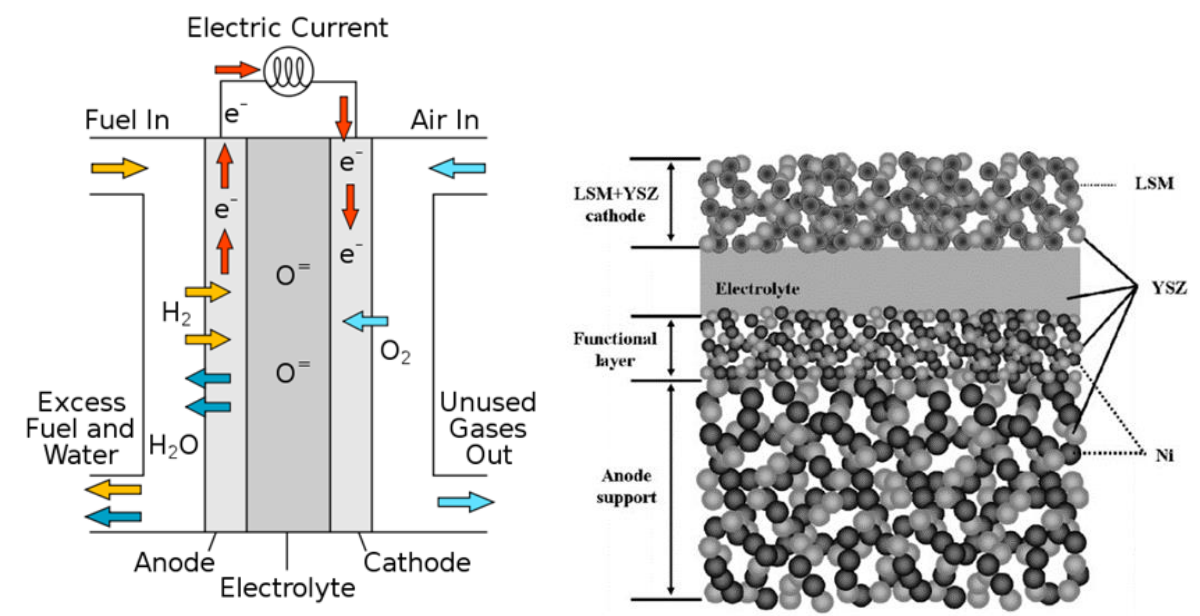

Figure.1 (a) Mechanism of a solid-oxide fuel cell (b) schematic of anode-supported SOFC single cell[5]

SOFCs (solid oxide fuel cell) are electrochemical devices that produce electricity directly from oxidizing fuels. Compared to direct combustion of hydrogen to generate power, it has a big advantage on efficiency. In our case, the fuels can be hydrogen or hydrocarbons. Figure.1 (by Sakurambo) shows a conventional schematic image of SOFC structure and how SOFCs generate power. SOFCs usually consist of three main components: anode, electrolyte and cathode. The conventional ceramic anode layer must have a porous structure to allow the fuel gas flow towards the electrolyte to realize the electrochemical reaction. As a result, granular matter or powder is often used for anode fabrication procedures[6]. The oxygen-ion 
conducting electrolyte is a dense layer which conducts oxygen ions to the anode side that react with the fuels including hydrogen, methane, ethane, methanol, acetone and other hydrocarbons. An important aspect of electrolyte is the shielded function of electrons which has a great influence on the overall performance of the SOFCs. Generally speaking, there are three popular electrolyte materials widely used for our researches nowadays, including yttria-stabilized zirconia (YSZ), scandia stabilized zirconia (ScSZ) and gadolinium doped ceria (GDC)[7]. Cathode is a porous structure where oxygen reduction takes place and oxygen vacancies form. Cathode materials have to be conductive and have a similar thermal expansion to electrolyte like YSZ or GDC to remain structurally and chemically stable during the test of cells at elevated temperatures.

In recently years, anode-supported fuel cells have been drawing the attention from all over the world because they can achieve both high performance at relatively low temperature and perform great thermodynamically mechanical stability[8]. Another great advantage of anode-supported fuel cell is that it allows direct internal methane reforming on the porous support material so that the conversion of methane to hydrogen can be transformed from a huge plant to a small part of anode as long as the conversion rate remains high and stable during the reforming process. Then, anode-supported fuel cells always have a smaller internal resistance compared to electrolyte-supported cells because of the much thinner electrolyte. The resistance of electrolyte is the main reason for the voltage drop within a cell during the test.

Among many kinds of anode materials that have a good catalytic reforming and electrochemical reactivity, Ni/YSZ is the most commonly used because of its cost-effective and well suitable for anodesupported fuel cell design requirements[9]. Moreover, Ni/YSZ anode containing 40-60\% (mass ratio) nickel has a similar thermal expansion coefficient compared to YSZ[10], which balances the catalytic and conductive ability very well and thus becomes a great candidate for anode material. Figure.1 (b)[5] shows a schematic image of Ni-based anode-supported SOFC. LSM+YSZ are used as cathode materials and dense YSZ is used for electrolyte. Anode can be divided into two layers: anode functional layer and anode conductive layer. For the structure in Figure.1 (b), anode functional layer is about 30um in thickness and this is where hydrogen oxidation reaction takes place and power comes out. For the anode conductive layer, 
porous $\mathrm{Ni} / \mathrm{YSZ}$ is used as the backbone of the cell structure. Methane or other hydrocarbons like methanol[11], ethanol[12] are pumped in and become hydrogen and carbon monoxide for power generation on the functional layer. With an anode-supported SOFC having high catalytic activity of methane steam reforming reaction, we can directly pump in methane or other hydrocarbons without any external reformer and thus a big amount of money spent on reactors, plants and industrial land can be saved.

At the same time, despite of these advantages for Ni-based anode material, some problems like sulfur poisoning, instability at high temperature, carbon deposition, are still limiting the wide application of this material. Among the challenges of limitation listed above, the biggest one is the performance degradation of fuel cell caused by solid carbon formation on the surface of the Ni/YSZ anode cermet.

Carbon deposition on the Ni/YSZ cermet anode materials mainly happen through the following three chemical reactions[13], shown in Equation (2) (3) and (4): a) Methane decomposition at high temperature and low steam to carbon ratio; b) Boudouard reaction occurs at low temperatures because of high concentration of $\mathrm{CO}$; c) Reduction of carbon monoxide by hydrogen produced by previous reactions. The reverse reaction of Equation (4) can also be used as a pathway to remove surface coke, which we will discuss in the following section.

$$
\begin{aligned}
& \mathrm{CH}_{4} \Leftrightarrow \mathrm{C}+2 \mathrm{H}_{2} \quad \Delta H=75 \mathrm{KJ} / \mathrm{mol} \\
& 2 \mathrm{CO} \Leftrightarrow \mathrm{C}+\mathrm{CO}_{2} \quad \Delta H=-172 \mathrm{KJ} / \mathrm{mol} \\
& \mathrm{CO}+\mathrm{H}_{2} \Leftrightarrow \mathrm{C}+\mathrm{H}_{2} \mathrm{O} \quad \Delta \mathrm{H}=-131 \mathrm{KJ} / \mathrm{mol}
\end{aligned}
$$

\begin{tabular}{|c|c|c|c|c|c|c|c|c|}
\hline Catalyst & $\begin{array}{l}\mathrm{Ni} \\
(\%)\end{array}$ & $\begin{array}{l}\mathrm{MgO} \\
(\%)\end{array}$ & $\begin{array}{l}\mathrm{CaO} \\
(\%)\end{array}$ & $\begin{array}{l}\mathrm{Al}_{2} \mathrm{O}_{3} \\
(\%)\end{array}$ & $\begin{array}{l}S_{\mathrm{BET}} \\
\left(\mathrm{m}^{2} / \mathrm{g}_{\mathrm{cat}}\right)\end{array}$ & $\begin{array}{l}S_{\mathrm{Ni}^{2}} \\
\left(\mathrm{~m}^{2} / \mathrm{g}_{\mathrm{cat}}\right)\end{array}$ & $\begin{array}{l}D p^{1} \\
(\mathrm{~nm})\end{array}$ & $\begin{array}{l}D p^{2} \\
(\mathrm{~nm})\end{array}$ \\
\hline $\mathrm{Ni} / \mathrm{HT} 30$ & 12.5 & 24.5 & & 59.6 & 271 & 8.6 & 12 & 12 \\
\hline $\mathrm{Ni} / \mathrm{HT} 50$ & 12.5 & 42.6 & & 41.5 & 201 & 4.2 & 24 & 23 \\
\hline
\end{tabular}

Table.1 Catalyst composition and BET surface area of each catalyst[14] 

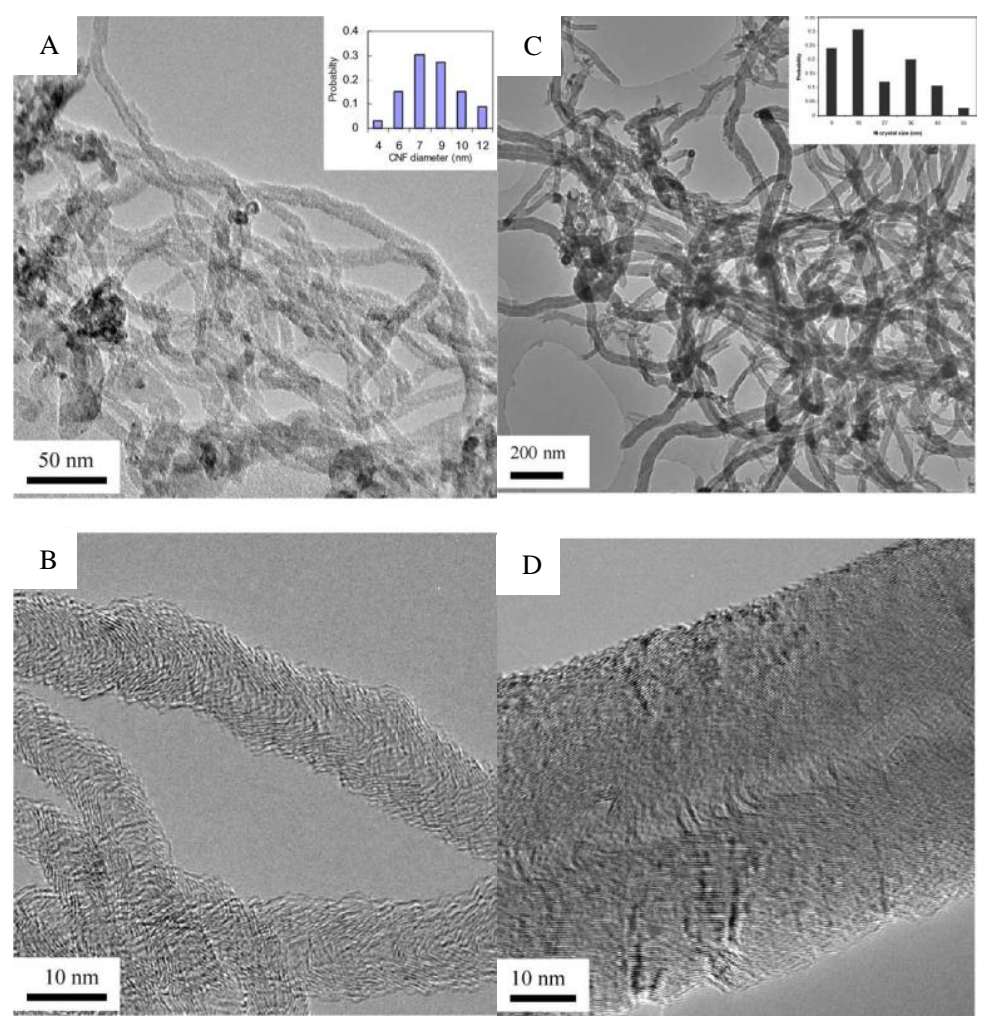

Figure.2 TEM images of carbon nanofibers (CNFs) produced on Ni/HT30 (A)(B) and Ni/HT50 (C)(D) at $650 \mathrm{~K}[14]$

The morphology and amount of carbon deposition depend on the reactants, anode materials and operation temperature of the cells[15]. Figure.2[14] are the HR-TEM pictures of different mythologies of carbon nanofibers at different composition of $\mathrm{Ni} / \mathrm{MgO} \mathrm{Al} \mathrm{Al}_{2} \mathrm{O}_{3}$ support. The $\mathrm{CNF}$ diameter produced on $\mathrm{Ni} / \mathrm{HT} 30$ is smaller than that produced on Ni/HT50, which indicates that anode support materials can greatly influence the morphology of the generated carbon.

Furthermore, Ni catalyst on anode-supported fuel cells can be damaged by the formation of the carbon whiskers or nanofibers, which have a high hardness, leading to the appearance of cracks on the surface of catalysts. Another big disadvantage of the carbon deposition is that it can block the active sites thereby inhibiting gas transportation, preventing reforming reactions by blocking the triple-phase boundary (TPB)[16]. The detailed mechanism of carbon formation will be illustrated in the following section. 


\section{Carbon deposition and its mechanism on Ni-YSZ catalyst for methane steam reforming}

The main composition of natural gas is methane, and the Ni-Y2O3-stabilizied zirconia (Ni-YSZ) catalyzes the steam methane reforming at high temperature, usually from $700^{\circ} \mathrm{C}$ to $900^{\circ} \mathrm{C}$. The advantages of Ni-YSZ as anode materials has been illustrated in the previous part. In this part, carbon deposition thermodynamics and kinetics from catalytic view will be based on this particular material. In order to get a deep understanding of the coke formation for methane steam reforming, we must study the thermodynamics and kinetics of it because we want the highest production of hydrogen along with the highest methane conversion rate. Carbon deposition is only a side product which can deactivate catalysts and even crack the anode electrode of SOFC. The activity of the catalyst will be significantly affected by the nature of the deposited carbon, which including the amount, the shape and the distribution.

The phenomenon of carbon deposition on the catalyst surface is shown in Figure.3 [17]. Carbon may chemisorb strongly as a monolayer or physically adsorb in multilayers to block access of the reactant to active metal surface sites. Shalini Arora and co-workers[18] listed different types of carbon species deposited during methane drying reforming process in Table.2 . Carbon forms different shapes on different temperatures and supports, thus the influence to catalysts is also quite different. Some forms of carbon decrease the catalyst activity by blocking the sites or plugging the pores to deactivate the anode. As shown in Table.3[19], deactivation and failure of methane steam reforming catalysts at high reaction temperature $\left(500-900^{\circ} \mathrm{C}\right)$ may be caused by a $50-70 \mathrm{~nm}$-layer of dissolved carbon on the Ni surface. If carbon atoms continue to gather on the Ni surface, adsorption and reaction process will be slowed down until a complete termination[19].

From the view of thermodynamic, factors like temperature, pressure and ratio of feedstock, all greatly influence the conversion rate of methane and the fraction of hydrogen production[20]. These important factors also show big effect on carbon deposition morphology which has been illustrated. For 
industrial production of hydrogen, regions of carbon forming potential in hydrocarbon steam reforming could be carefully avoided. The filamentous carbon grows at an extremely high speed and causes catastrophic pore plugging. By using this catalytic property of $\mathrm{Ni}$ on carbon accumulation and growth, some researchers $[14,21,22]$ even synthesis filamentous carbon or other shapes of carbon on different conditions for multiple uses.

On the other hand, sometimes it is difficult to suppress carbon deposition in industrial production due to the cost of related equipment or other reasons, which means coke may occur thermodynamically. For example, more steam benefits the conversion of methane for methane steam reforming and decreases of coke based on thermodynamic calculation. However, it is quite expensive to generate more steam because of the cost on generators and accessories. At the same time, the maintenances of the whole system cost a lot. So we must think of a way from the kinetic aspect to suppress this deactivating agent. Providing SOFCs with fuels containing hydrocarbons leads to the risk of depositing carbon on the anode[23, 24]. In the beginning, the investigations on methane steam reforming reaction have been mainly studied on the preparation of catalyst and process analysis. While in the past forty years, the kinetics and the reaction mechanisms have also been addressed [25-27] to propose coherent reaction mechanism. Carbon deposition is a side product which can degrade the catalyst and methane conversion rate. Equation (1) and Equation (2) mentioned above are two main sources for carbon deposition on Ni catalyst surface. So if we want to study the kinetics of carbon formation on catalyst surfaces, we must focus on the homogenous global reactions during methane steam reforming and give detailed expressions on the reactions we are interested in, which are the reactions related to coke. 


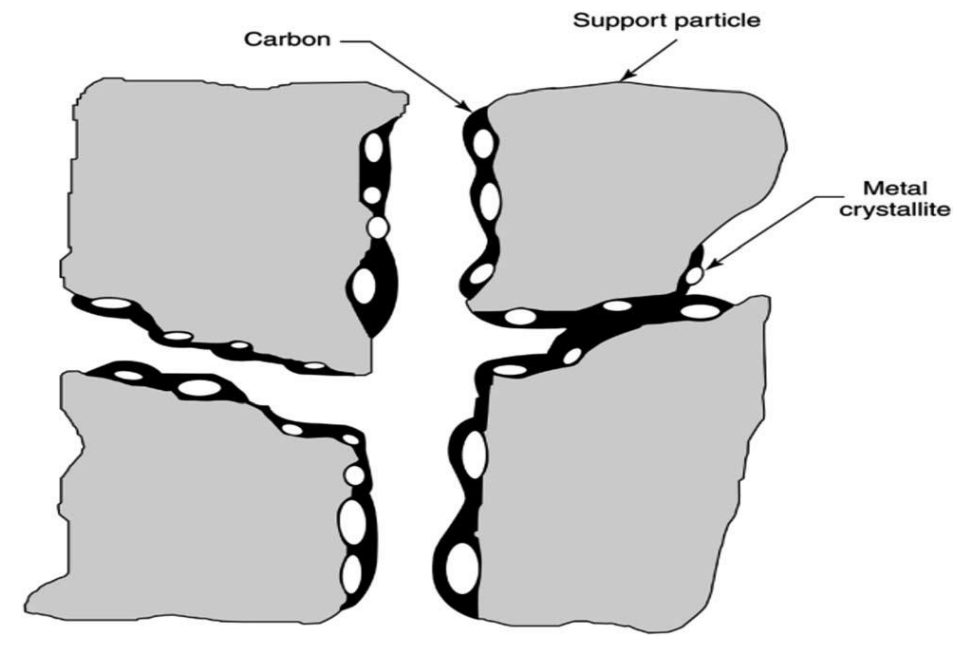

Figure 3. Pore plugging in a supported metal catalyst owing to carbon deposition

Table.2 Details of different carbon species formed on the catalyst surface

\begin{tabular}{|lll|}
\hline Carbon structure & Designation & $\begin{array}{l}\text { Temperature } \\
\text { range }\left({ }^{\circ} \mathrm{C}\right)\end{array}$ \\
\hline $\begin{array}{l}\text { Adsorbed, atomic carbon } \\
\text { (surface carbide) }\end{array}$ & $\mathrm{C}_{\alpha}$ & $200-400$ \\
$\begin{array}{l}\text { Polymers, amorphous films } \\
\text { Ni carbide (bulk) }\end{array}$ & $\mathrm{C}_{\beta}$ & $250-500$ \\
Vermicular filaments or whiskers & $\mathrm{C}_{\gamma}$ & $150-250$ \\
Graphite (crystalline) platelet films & $\mathrm{C}_{\mathrm{v}}$ & $300-1000$ \\
& $\mathrm{C}_{\mathrm{c}}$ & $500-550$ \\
\hline
\end{tabular}

Table.3 Carbon species formed in steam reforming of hydrocarbons on Ni catalysts

\begin{tabular}{|c|c|c|c|}
\hline Attribute & Encapsulating film & Whisker-like & Pyrolytic carbon \\
\hline Formation & $\begin{array}{l}\text { Slow polymerization of } \\
\mathrm{C}_{n} \mathrm{H}_{m} \text { radicals on } \mathrm{Ni} \\
\text { surface, into } \\
\text { encapsulating film }\end{array}$ & $\begin{array}{l}\text { Diffusion of } \mathrm{C} \text { through } \mathrm{Ni} \\
\text { crystal, nucleation and } \\
\text { whisker growth with } \mathrm{Ni} \\
\text { crystal at top }\end{array}$ & $\begin{array}{l}\text { Thermal cracking of } \\
\text { hydrocarbon; deposition } \\
\text { of C precursors } \\
\text { on catalyst }\end{array}$ \\
\hline Effects & $\begin{array}{l}\text { Progressive } \\
\text { deactivation }\end{array}$ & $\begin{array}{c}\text { No deactivation of } \mathrm{Ni} \\
\text { surface. Breakdown of } \\
\text { catalyst and increasing } \Delta P\end{array}$ & $\begin{array}{c}\text { Encapsulation of catalyst } \\
\text { particle; deactivation and } \\
\text { increasing } \Delta P\end{array}$ \\
\hline Temp. range, ${ }^{\circ} \mathrm{C}$ & $<500$ & $>450$ & $>600$ \\
\hline Critical parameters & $\begin{array}{l}\text { Low temperature, low } \\
\qquad \mathrm{H}_{2} \mathrm{O} / \mathrm{C}_{n} \mathrm{H}_{m} \text {, low } \\
\mathrm{H}_{2} / \mathrm{C}_{n} \mathrm{H}_{m} \text {, aromatic feed }\end{array}$ & $\begin{array}{l}\text { High temperature, low } \\
\mathrm{H}_{2} \mathrm{O} / \mathrm{C}_{n} \mathrm{H}_{m} \text {, no enhanced } \\
\mathrm{H}_{2} \mathrm{O} \text { adsorption, low } \\
\text { activity, aromatic feed }\end{array}$ & $\begin{array}{l}\text { High temperature, high } \\
\text { void fraction, low } \\
\quad \mathrm{H}_{2} \mathrm{O} / \mathrm{C}_{n} \mathrm{H}_{m} \text {, high } \\
\text { pressure, acidic catalyst }\end{array}$ \\
\hline
\end{tabular}




\subsection{Thermodynamic calculations and experiments of carbon deposition for methane steam reforming}

\subsubsection{Methane steam reforming thermodynamics}

Methane steam reforming is the current commercial method for syngas production in petrochemical and industrial scale plants. The syngas is used for the chemical, petrochemical and refinery industries for producing methanol, ammonia and other hydrocarbons with higher added value[28]. The process of methane steam reforming requires a large amount of energy, which combining methane steam reforming and water gas shift reaction together[29, 30]. Water gas shift reaction (WGSR) is a low exothermic reaction in nature and is expressed by Equation (6). It is also a path of hydrogen production.

$$
\begin{array}{cc}
\mathrm{CH}_{4}+\mathrm{H}_{2} \mathrm{O} \leftrightarrow \mathrm{CO}+3 \mathrm{H}_{2} & \Delta H_{298}^{0}=206 \mathrm{KJ} / \mathrm{mol} \\
\mathrm{CO}+\mathrm{H}_{2} \mathrm{O} \leftrightarrow \mathrm{CO}_{2}+\mathrm{H}_{2} \quad \Delta H_{298}^{0}=-46 \mathrm{KJ} / \mathrm{mol}
\end{array}
$$

In order to analyze the thermodynamic equilibrium of all the variables at any temperature and pressure, multicomponent mixture must be considered properly. Previous works have been presented the application of Gibbs free energy minimization method for various fuels reacted with steam or carbon dioxide, such as methane [31-33], ethanol[12], propane[34], glycerol[35]. Other computations of the equilibrium constants based on standard $\Delta \mathrm{H}$ and $\Delta \mathrm{G}$ values [36, 37], entropy maximization calculations [28] are also used to study the thermodynamic system related to hydrogen production or reforming process.

While, the Gibbs minimization method has been widely used because of its simplicity and its ability to calculate equilibrium compositions even for systems where the reaction pathways are unknown. By using the minimization of Gibbs free energy method, we can quantitatively predict product distribution at equilibrium conditions in a quite complicated system. For the system we are now interested in, the compositions of methane steam reforming can contain $\mathrm{CH} 4, \mathrm{CO} 2, \mathrm{CO}, \mathrm{H} 2, \mathrm{H} 2 \mathrm{O}$ and solid carbon when coke is considered. 
The method of Gibbs free energy minimization to study the thermodynamic of methane steam reforming or other hydrocarbon reforming is quite similar[20]. The total Gibbs free energy of a chemical reactive system is given by Equation (7).

$$
\begin{gathered}
G^{t}=\sum_{i=1}^{N} n_{i} u_{i} \\
u_{i}=\Delta G_{f_{i}}^{o}+R T \ln \left(\frac{\widehat{f}_{l}}{f_{i}^{0}}\right)
\end{gathered}
$$

The total of Gibbs free energy at constant temperature and pressure, the number of species in the feed and the mole of species are presented by Gt, $\mathrm{N}$ and ni respectively. Equation (8) is the chemical potential of the whole system.

Where $\widehat{f}_{l}$ is the fugacity in the system and $f_{i}^{0}$ refers to the standard fugacity and both can be given as:

$$
\begin{aligned}
\widehat{f}_{l} & =y_{i} \widehat{\emptyset}_{l} P \\
f_{i}^{0} & =P_{0}
\end{aligned}
$$

Where $\emptyset_{i}$ is the fugacity coefficient of species i in the feedstock, which can be calculated by using the Virial equation of state, and yi the molar fraction of species i, R is the universal gas constant, $\Delta G_{f_{i}}^{o}$ is the standard Gibbs energy of formation, that related only to temperature and reports in some references. Study of the equilibrium conditions in the gas phase by introducing the Lagrangian multiplier leads to Equation (11)

$$
\sum_{i}^{N} n_{i}\left(\Delta G_{f_{i}}^{o}+R T \ln \left(\frac{\widehat{f}_{l}}{f_{i}^{0}}\right)+\sum_{k} \lambda_{i} a_{i k}\right)=0(11)
$$

Amount of Gibbs free energy and enthalpy of formation for the present composition in the system are shown in Table.4 [38]. Softwares like MATLAB[20, 39], Aspen-SYSYS 2006[33], Aspen Plus[40] are commonly used to study the multi-compositions in the system. 
Table 4. A list of amounts of enthalpy and Gibbs free energy of formation[38]

\begin{tabular}{ccc}
\hline Species & $\Delta H_{298}^{\circ}\left(\frac{\mathrm{kJ}}{\mathrm{mol}}\right)$ & $\Delta G_{298}^{\circ}\left(\frac{\mathrm{kJ}}{\mathrm{mol}}\right)$ \\
\hline $\mathrm{CH}_{4}$ & -74.5 & -50.5 \\
$\mathrm{CO}$ & -110.5 & -137.2 \\
$\mathrm{CO}_{2}$ & -393.5 & -394.4 \\
$\mathrm{H}_{2}$ & 0 & 0 \\
$\mathrm{H}_{2}$ & -241.8 & -228.6 \\
$\mathrm{O}_{2}$ & 0 & 0 \\
$\mathrm{C}$ & 0 & 0 \\
\hline
\end{tabular}

For the methane steam reforming reaction, methane conversion rate, selectivity of hydrogen are main factors to evaluate the quality of catalyst and reforming, which show the efficiency of the catalytic process[28]. Although the existence of some inevitable side reactions causes the inaccuracy in hydrogen production such as Equation (2)-(4), higher methane conversion rate indicates higher hydrogen production to some extent and thus a better performance for power generation in solid oxide fuel cells. To study the performance of methane steam reforming under different carbon to steam ratio, temperature and pressure, theoretical calculations and practical experiments were performed to optimize the ratio in different situations.

Farshad Farshichi Tabrizi and co-workers[20] studied hydrogen production in the ranges of steam to methane ratio from 0.5 to 3 , reaction pressure from 1 to 50 bar ( 0.1 to 5 atmosphere) and operative temperature from 600 to $1200 \mathrm{~K}$ using Gibbs free energy minimization method. 3-D images were plotted to clearly illustrate the influence of carbon to steam ratio, temperature and pressure to methane conversion and hydrogen selectivity. Figure.4 (a) shows that the temperature significantly change the methane conversion rate. Due to the endothermic property of methane steam reforming reaction, we can also see the methane conversion increases with the growing temperature in the range of $600-1200 \mathrm{~K}$. The reaction favors low pressure, which can be noticed from Equation (1). Figure 4(a) also told the same trend. It is clear that methane conversion was increased with the increasing temperature and inlet steam to carbon. 

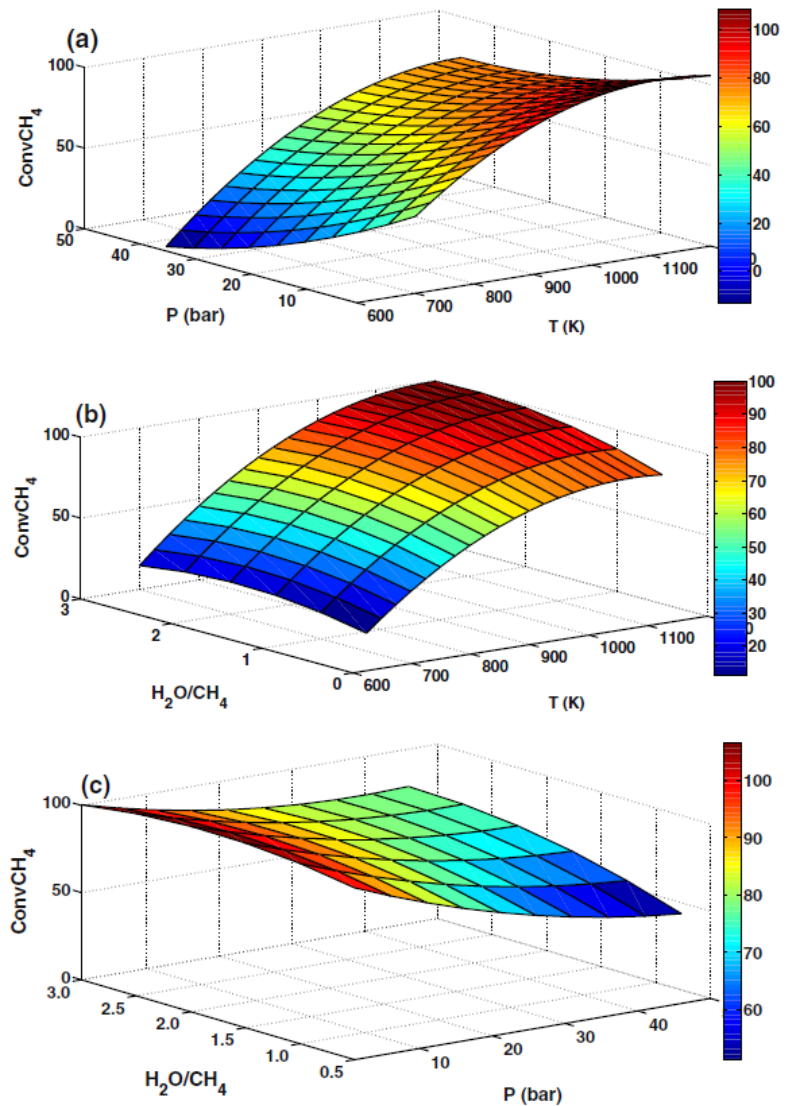

Figure.4 Conversion of methane as re and the inlet $\left(\mathrm{H}_{2} \mathrm{O} / \mathrm{CH}_{4}\right)$ a function of the (a) temperature and pressure (b) temperature (c) pressure and the inlet $\left(\mathrm{H}_{2} \mathrm{O} / \mathrm{CH}_{4}\right)$

$$
\begin{gathered}
\mathrm{ConvCH}_{4}=-3.25019+0.00770488 \times \mathrm{T}-0.0317249 \times \mathrm{P}+0.0354457 \times\left(\frac{\mathrm{H} 2 \mathrm{O}}{\mathrm{CH} 4}\right)-3.5056 \times 10^{-6} \times \\
T^{2}+0.000151511 \times P^{2}-0.0444696 \times\left(\frac{\mathrm{H} 2 \mathrm{O}}{\mathrm{CH} 4}\right)^{2}+1.32682 \times 10^{-5} \times T^{2}+0.000127971 \times T \times\left(\frac{\mathrm{H} 2 \mathrm{O}}{\mathrm{CH} 4}\right)+ \\
0.00225275 \times P \times\left(\frac{\mathrm{H} 2 \mathrm{O}}{\mathrm{CH} 4}\right)
\end{gathered}
$$

After theoretical charts illustration, Equation (12) was calculated and shown to describe the relations between the methane conversion and three main parameters. All these three parameters are important and temperature is the most significant one because of the quadratic term in the equation, which perfectly matched the results shown in Figure.4. Moreover, the interaction of temperature with inlet and interaction of pressure with inlet has no important influence on the methane conversion. 

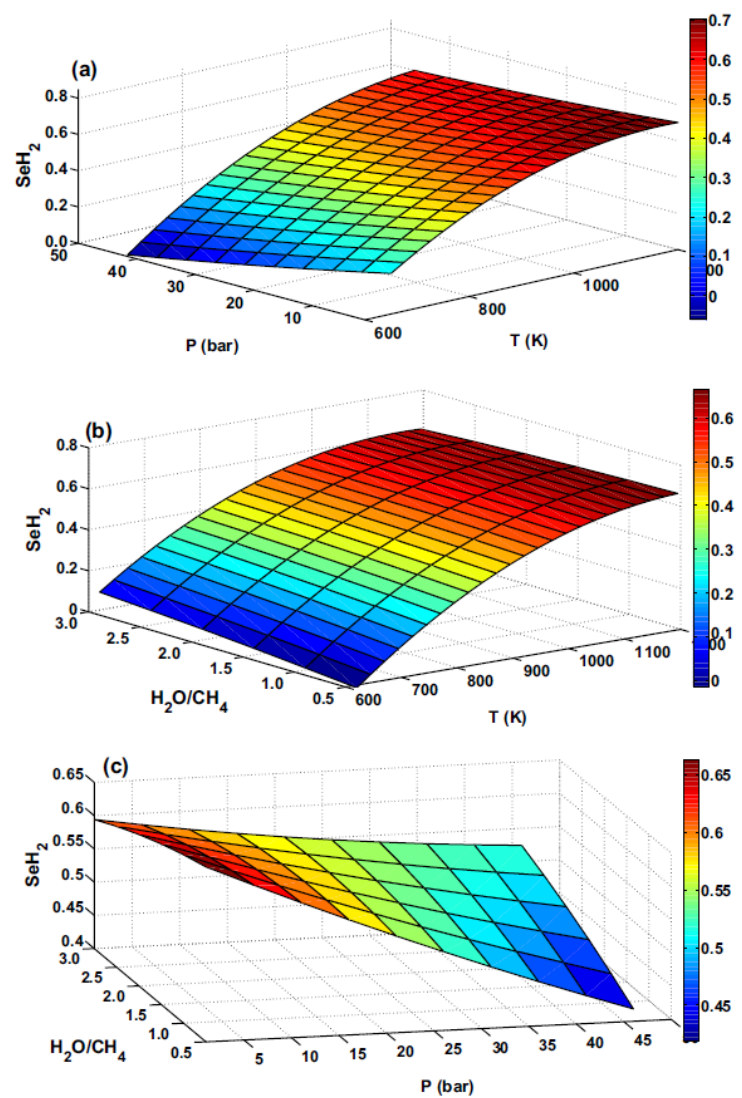

Figure.5 Selectivity of hydrogen as a function of the (a) temperature and pressure (b) temperature and the inlet $\left(\mathrm{H}_{2} \mathrm{O} / \mathrm{CH}_{4}\right)$ (c) pressure and the inlet $\left(\mathrm{H}_{2} \mathrm{O} / \mathrm{CH}_{4}\right)$

$$
\begin{gathered}
\mathrm{Se} H_{2}=-1.86471+0.0436689 \times T-0.0143190 \times P+0.0889709 \times\left(\frac{\mathrm{H} 2 \mathrm{O}}{\mathrm{CH} 4}\right)-1.80847 \times 10^{-6} \times T^{2}+ \\
1.76412 \times 10^{-5} \times P^{2}-0.0040311 \times\left(\frac{\mathrm{H} 2 \mathrm{O}}{\mathrm{CH} 4}\right)^{2}+7.42532 \times 10^{-6} \times T \times P-1.06151 \times 10^{-4} \times T \times\left(\frac{\mathrm{H} 2 \mathrm{O}}{\mathrm{CH} 4}\right)+ \\
0.00155363 \times P \times\left(\frac{\mathrm{H} 2 \mathrm{O}}{\mathrm{CH} 4}\right)
\end{gathered}
$$

Hydrogen selectivity has also been studied, as shown in Figure.5. Hydrogen is the main production we desire for the next electrochemical reaction on anode material to generate power in SOFCs. It is evident that the high hydrogen production favors low pressure. As also clearly visible in Figure.5 (a), the effect of pressure at high temperature is far weaker than that at low temperature, which indicates the big effect of temperature on hydrogen selectivity. On the condition of temperature and steam to methane ratio, 
temperature is also the dominant parameter according to Figure.5 (b). When considering the influence of inlet ratio and system pressure, we can see a linear behavior on the selectivity of hydrogen.

Equation (13) was calculated to show the mathematical modeling selectivity of hydrogen in methane steam reforming with all operational conditions including temperature. Same conclusions can be drawn that the inlet ratio is almost a negligible variable, while temperature is a crucial parameter for hydrogen selectivity.

M.S Challiwala and his co-workers [39] used MATLAB to evaluate the potential of overcoming the limitations of dry reforming by integrating it with other commercial methane reforming technologies such as steam reforming and partial oxidation reforming in industrial operating conditions. They studied simultaneous effects of temperature $\left(200^{\circ} \mathrm{C}-1200^{\circ} \mathrm{C}\right)$, pressure $(1-20$ bar) and feed mole ratios (of methane, steam, carbon dioxide and oxygen). After calculation, the optimized operating condition of $750^{\circ} \mathrm{C}$ at 1 bar pressure at a feed mole ratio $\mathrm{CH} 4: \mathrm{H} 2 \mathrm{O}: \mathrm{O} 2: \mathrm{CO} 2$ of 1:0.4:0.3:1. At this condition, carbon deposition can be totally eliminated and $\mathrm{CO} 2$ conversion rate can be as high as $47.84 \%$.

Y.S.Seo and co-workers [41] have done some thermodynamic calculations and analysis on methane steam reforming (SMR), partial oxidation (POX) and auto-thermal reforming (ATR) by adjusting the temperature, reactor pressure, and carbon to steam ratio using AspenPlusTM. They calculated the optimum steam-to-carbon (S: C) ratio of the SMR and found it to be 1.9. After comparing the $\mathrm{CH} 4$ flow rate required to generate $1 \mathrm{~mol} / \mathrm{s}$ of hydrogen, they demonstrated that partial oxidation reforming system has the lowest energy cost because of the least methane consumed.

Thermodynamic calculation on steam reforming of other hydrocarbon was also investigated. Sushil Adhikari[42] studied the steam reforming of glycerol for hydrogen production. To reach the high production of hydrogen, high temperature is also need, usually higher than $900 \mathrm{~K}$. A high molar to glycerol can not only benefit the yield of hydrogen, but can also minimize some of the side productions like methane and carbon. 


\subsubsection{Thermodynamics of carbon deposition for methane steam reforming}

Thermodynamic calculation of methane steam reforming is shown in the previous part of this report. Presence of carbon deposition coming from the methane pyrolysis described by Equation (2) leads to rapid deactivation of catalyst by covering the active sites available for reactions. While, this side product caused by complicated reactions in methane steam reforming system can be partially eliminated by choosing the right operational conditions through thermodynamic approaches.

Further developing of Equation (11) by Farshad Farshchi Tabrizi[20] to calculate coke formation, graphite was considered in the list of component collection. However, Gibbs free energy of graphite formation is zero thus it was only calculated in the elemental constraints. By using minimization of Gibbs free energy method, the final form of main equation is shown in Equation (14).
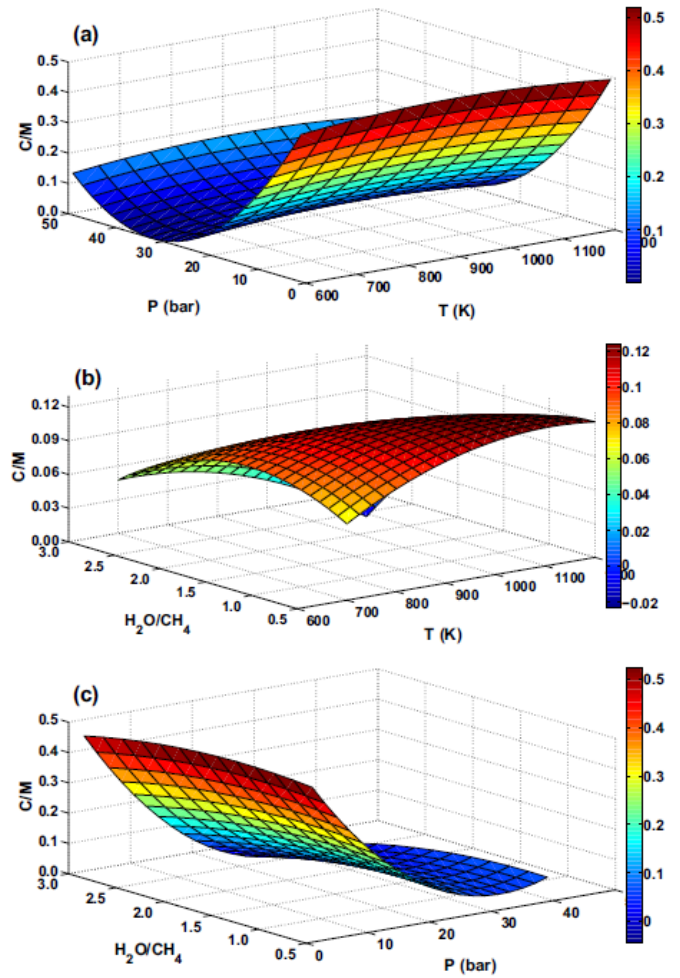

Figure.6 Coke formation as a function of the (a) temperature and pressure (b) temperature and the inlet $\left(\mathrm{H}_{2} \mathrm{O} / \mathrm{CH}_{4}\right)$ (c) pressure and the inlet $\left(\mathrm{H}_{2} \mathrm{O} / \mathrm{CH}_{4}\right)$ 


$$
\sum_{i}^{N-1} n_{i}\left(\Delta G_{f_{i}}^{o}+R T \ln \left(\frac{\widehat{f}_{l}}{f_{i}^{0}}\right)+\sum_{k} \lambda_{i} a_{i k}\right)+\left(n_{c} \Delta G_{f_{c(s)}}^{o}\right)=0
$$

Figure.6 shows the amount of coke formation (number of moles of carbon at the equilibrium/inlet number of moles of $\mathrm{CH}_{4}$ ) or $\mathrm{C} / \mathrm{M}$ at the equilibrium condition as a function of temperature, pressure and steam to carbon ratio. $\mathrm{C} / \mathrm{M}$ is obviously mainly influenced by pressure and the amount of coke formation decreases in the increase in pressure till to $\mathrm{P}=32.9$ bar then it increases again. The elevation of temperature resulted to decomposition of methane according to Equation (1). Moreover, the increase in steam to carbon ratio strongly presented a negative effect on the coke presence because of the carbon gasification reaction which shows by Equation (15).

$$
\mathrm{C}+\mathrm{H}_{2} \mathrm{O} \leftrightarrow \mathrm{CO}+\mathrm{H}_{2}
$$

The full quadratic equation for coke formation is shown in Equation (16), which indicates that the effect of pressure on coke deposition is vital for long-term service of catalysts.

$$
\begin{gathered}
\frac{\mathrm{C}}{\mathrm{M}}=0.125015+6.07031 \times 10^{-5} \times T-0.00661950 \times P-0.0405367 \times\left(\frac{\mathrm{H} 2 \mathrm{O}}{\mathrm{CH} 4}\right)-1.43576 \times \\
10^{-8} \times T^{2} \times 9.67926 \times 10^{-5} \times P^{2}+0.00783472 \times\left(\frac{\mathrm{H} 2 \mathrm{O}}{\mathrm{CH} 4}\right)^{2}-1.70018 \times 10^{-7} \times T \times P-1.44237 \times \\
10^{-5} \times T \times\left(\frac{\mathrm{H} 2 \mathrm{O}}{\mathrm{CH} 4}\right)+0.000353826 \times P \times\left(\frac{\mathrm{H} 2 \mathrm{O}}{\mathrm{CH} 4}\right)
\end{gathered}
$$

As for the application of solid oxide fuel cell fueled with hydrocarbons, ternary diagram containing C-H-O is useful to predict the cell potential and coke formation. Tatsuya Takeguchi and his colleagues[43] calculated equilibrium partial pressure of oxygen and the boundary of carbon deposition region in the C$\mathrm{H}-\mathrm{O}$ diagram at temperature ranging from $400{ }^{\circ} \mathrm{C}$ to $1000{ }^{\circ} \mathrm{C}$ on Ni-YSZ cermet, which is the most commonly used anode material for solid oxide fuel cell. The contour map was shown in Figure.7. The broken lines showed the boundary of carbon deposition region in four pictures and the carbon deposition region is expected in carbon-rich compositions beyond the lines. The stars shown in the pictures indicated 
the highest theoretical cell voltage in the carbon free region because of the lowest oxygen partial pressure at the anode side.

Y.S.Seo and co-workers [41] have done some thermodynamic calculations and analysis on methane steam reforming by adjusting the temperature, reactor pressure, and carbon to steam ratio. Figure. 8 is a contour diagram that combines the conversion and $\mathrm{C}(\mathrm{s})$ mole fraction in terms of both the air ratio and the reactor temperature. Using the simulation, we can see that the optimum steam to carbon ratio in the steam methane reforming (SMR) is found to be 1.9 or more.
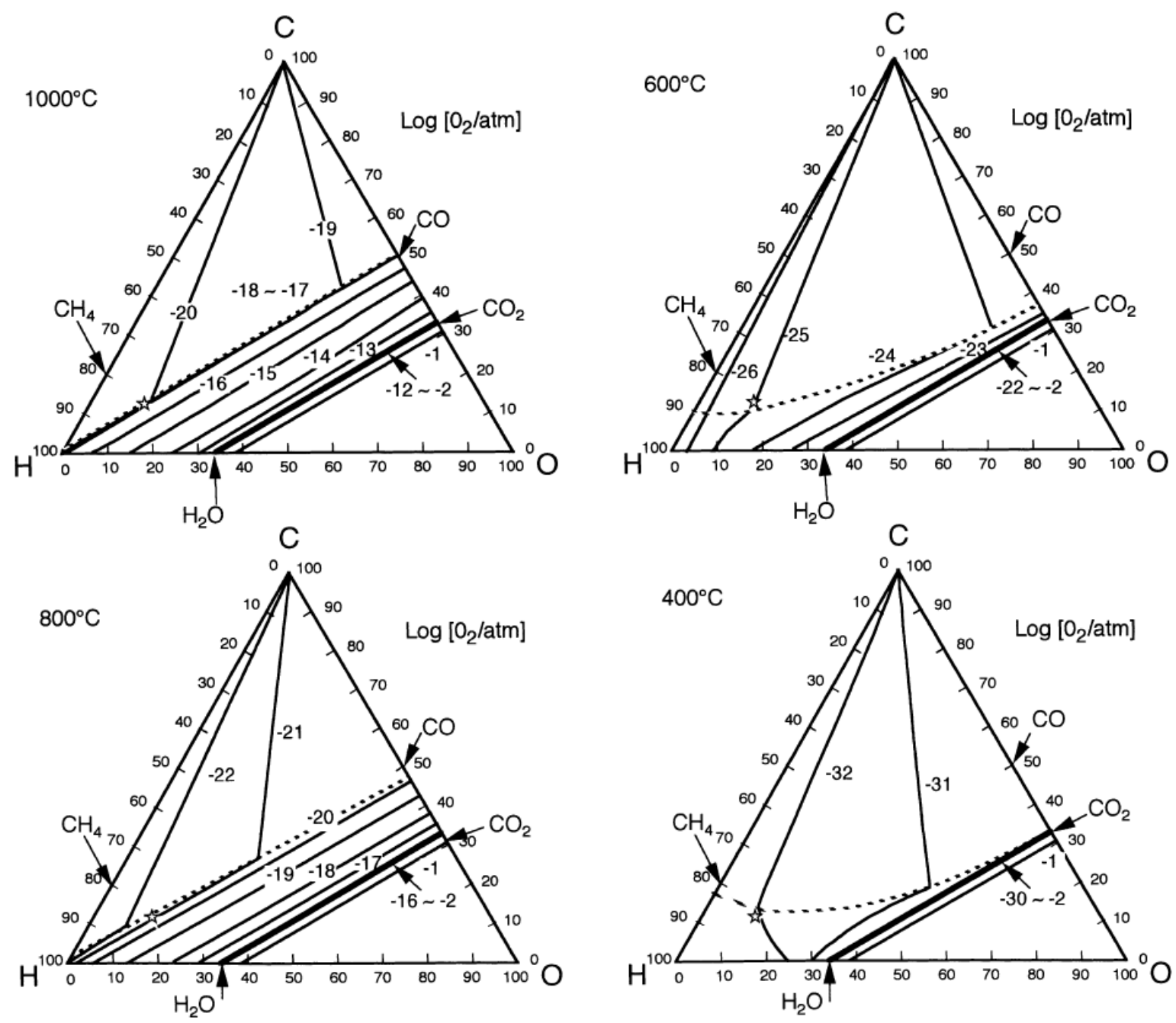

Figure.7 The equilibrium partial pressure of oxygen and the boundary of carbon deposition region in gas mixtures for the $\mathrm{C}-\mathrm{H}-\mathrm{O}$ diagram at temperatures ranging from 400 to $1000^{\circ} \mathrm{C}[43]$. 
Besides methane as a fuel gas for steam reforming, other kinds of hydrocarbon were also studied for the feed of steam reforming. Coke problems have also been studied for decades by thermodynamic analysis. S. Assabumrungrat [11] undertook a detailed thermodynamic analysis for carbon formation in a solid oxide fuel cell system with a direct internal reformer (DIR) fueled by methanol. The results indicated that carbon formation can be prevented by either increasing the inlet $\mathrm{H}_{2} \mathrm{O}: \mathrm{MeOH}$ ratio or by increasing the operating temperature, which is shown in Figure.9.

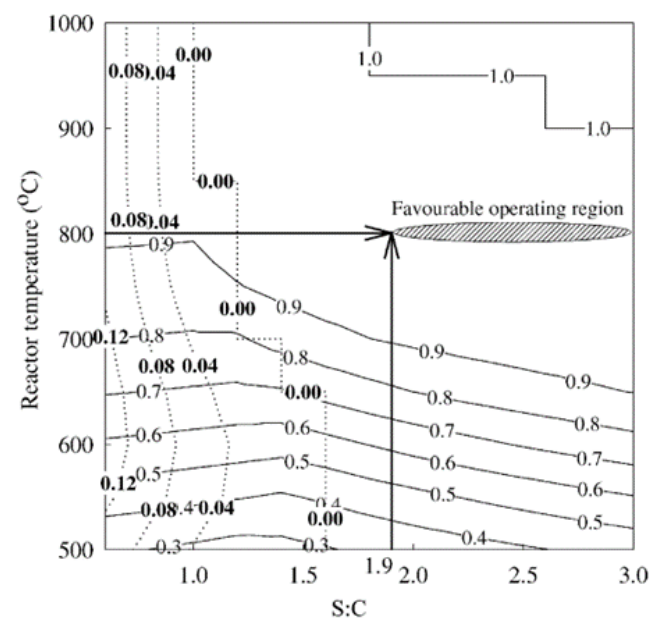

Figure.8[41] Contour diagram of $\mathrm{C}(\mathrm{s})$ and conversion with regard to both reactor temperature and $\mathrm{S}: \mathrm{C}$ ratio in SMR reactor. Reactor pressure, 1.0 bar; (- - -) C(s) mole fraction; (-) conversion.

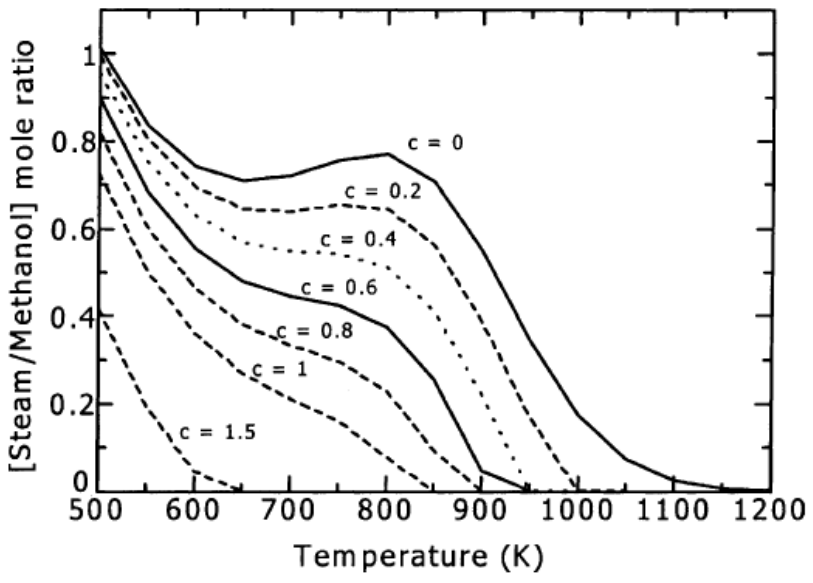

Figure.9 [11] Influence of extent of electrochemical reaction of hydrogen on requirement of inlet $\mathrm{H}_{2} \mathrm{O}: \mathrm{MeOH}$ ratio at different operating temperature 
Aline Lima da Silva [12] calculated the carbon deposition thermodynamic during ethanol steam reforming and found that at high contact times, for $\mathrm{T}>550 \mathrm{~K}$ an inlet steam/ethanol ratio of 3:1 would be suitable to perform steam reforming of ethanol without coke presence. For lower temperature like 400K, an inlet steam/ethanol ratio should be as high as 5:1 to prevent carbon deposition. The thermodynamic calculation result is shown in Figure.10.

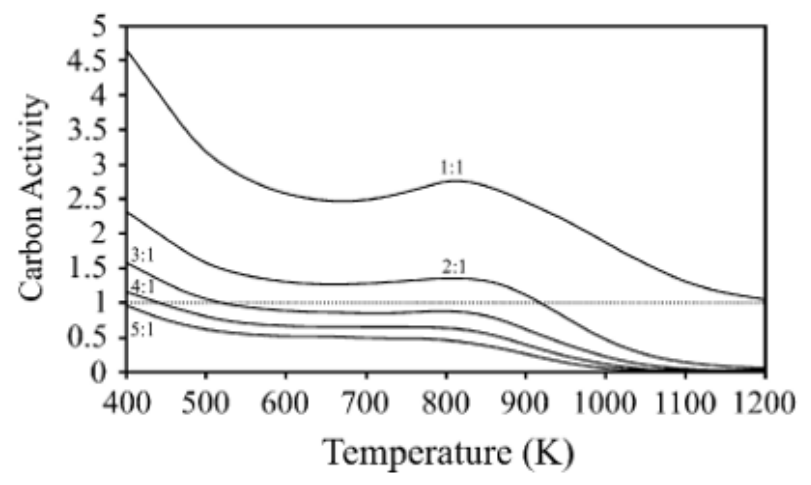

Figure.10[12] Carbon activities as function of temperature, for five inlet $\mathrm{H}_{2} \mathrm{O} / \mathrm{EtOH}$ ratios

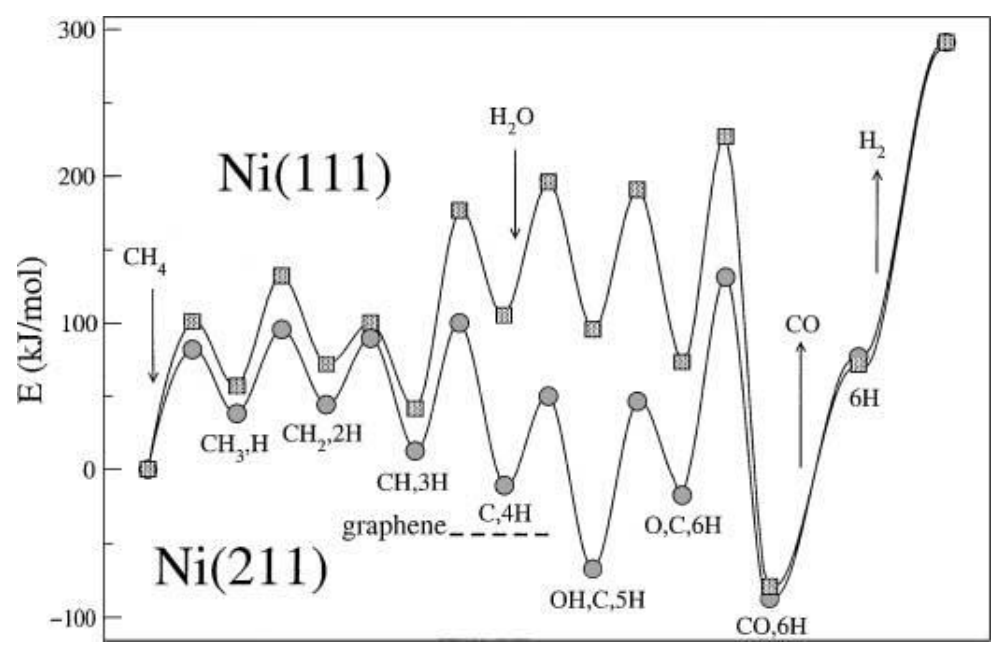

Figure.11 Energies for the species on $\mathrm{Ni}(211)$ and $\mathrm{Ni}$ (111). All energies are relative to $\mathrm{CH}_{4}$ and $\mathrm{H}_{2} \mathrm{O}$ in the gas phase and calculated using results for individual species[44] 
Many theoretical scientists [45-47] are also working on the simulations and calculations of carbon deposition. Density functional theory (DFT) is another computational quantum mechanical modeling method often applied to calculate the carbon deposition energy and issues related to similar problems. DFT was first proposed by Hohenberg and Kohn[48] as a branch of first-principles calculations based on the electron density. In 1983, Parr wrote a review to alert the promise of this theory in the description of chemical phenomena[49]. With time passing by, DFT theory has been further developed with different functions particularly when calculating different systems, which builds a tight and strong correlation between theoretical and experimental data in elemental physics and chemistry.

By using DFT calculations, H.S.Bengaard and co-workers[44] were able to propose that there were at least two kinds of active sites for steam reforming on Ni catalysts and gave an explanation of the reason why additives like potassium or gold can suppress the carbon formation. Figure. 11 concludes the results of density functional theory (DFT) calculations of methane steam reforming process over a Ni (111) surface and a stepped site Ni (211) surface. Two important features can be concluded:

- There are at least two reaction channels for carbon deposition. The step sites Ni (211) are much more active than close-packed surface $\mathrm{Ni}$ (111), which means carbon formation are likely to occur on step sites.

- Atomic carbon has much higher stability on steps than on terrace sites.

The carbon atoms adsorb on Ni surface chemically, but the adsorptive production remains undetected directly for quite a long time. While, Nabeel A. Jarrah and co-workers [21] first directly observed that before the formation of CNFs on polycrystalline Ni, C atoms combined with Ni to form a meta-stable compound $\mathrm{Ni}_{3} \mathrm{C}$ initially. Then the $\mathrm{Ni}_{3} \mathrm{C}$ decomposes into $\mathrm{Ni}$ and $\mathrm{C}$ because of its instability. Figure.12 shows the micrographs of $\mathrm{Ni}$ catalyst after short time exposure in $\mathrm{C}_{2} \mathrm{H}_{4}$ and $\mathrm{N}_{2}$ is used as protecting atmosphere. The initial stage of carbon formation can be observed from Figure.12 (a) (b) (c). After a long time of exposure, the carbon nanofibers become larger and Ni particles are lifted from the bottom of the surface to the very tiny tips of carbon nanofibers according to Figure.12 (d) (e) (f). Figure.13 
[50] is the $\mathrm{XRD}$ patterns evidence of $\mathrm{Ni}_{3} \mathrm{C}$ observation which matches very well with Figure.12(b) in contrast to longer times of exposure to ethylene.
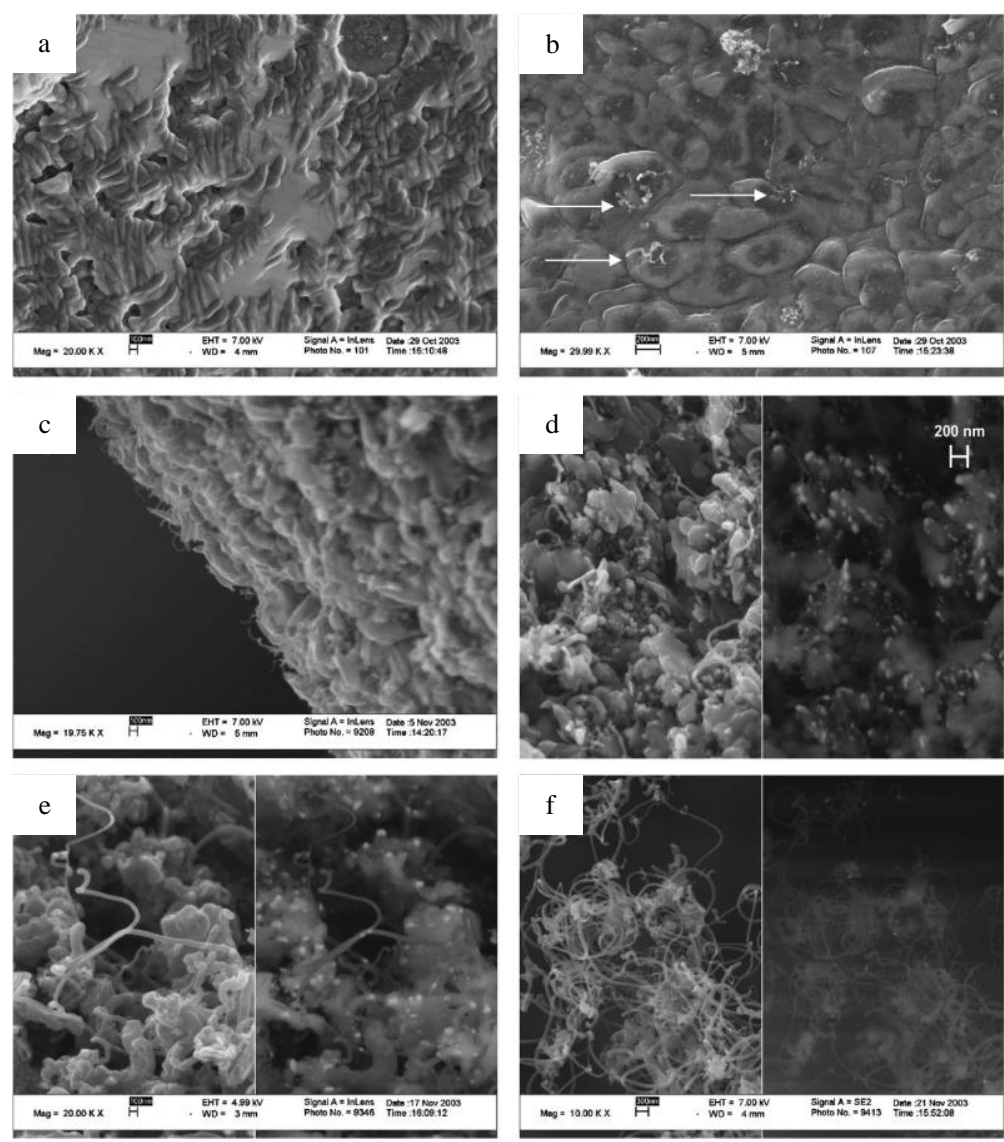

Figure.12 SEM micrographs of the surface of $\mathrm{Ni}$ foam (reduced at $700^{\circ} \mathrm{C}$ ) after exposure to $25 \% \mathrm{C}_{2} \mathrm{H}_{4}$ in $\mathrm{N}_{2}$

(total flow rate $107 \mathrm{~mL} / \mathrm{min}$ ) at $450{ }^{\circ} \mathrm{C}$ during (a) $1 \mathrm{~min}$, (b) $5 \mathrm{~min}$, (c) $20 \mathrm{~min}$, (d) $30 \mathrm{~min}$, (e) $60 \mathrm{~min}$, (f) 120 min; in the right-hand panels in micrographs (d), (e), and (f) Ni particles show bright.

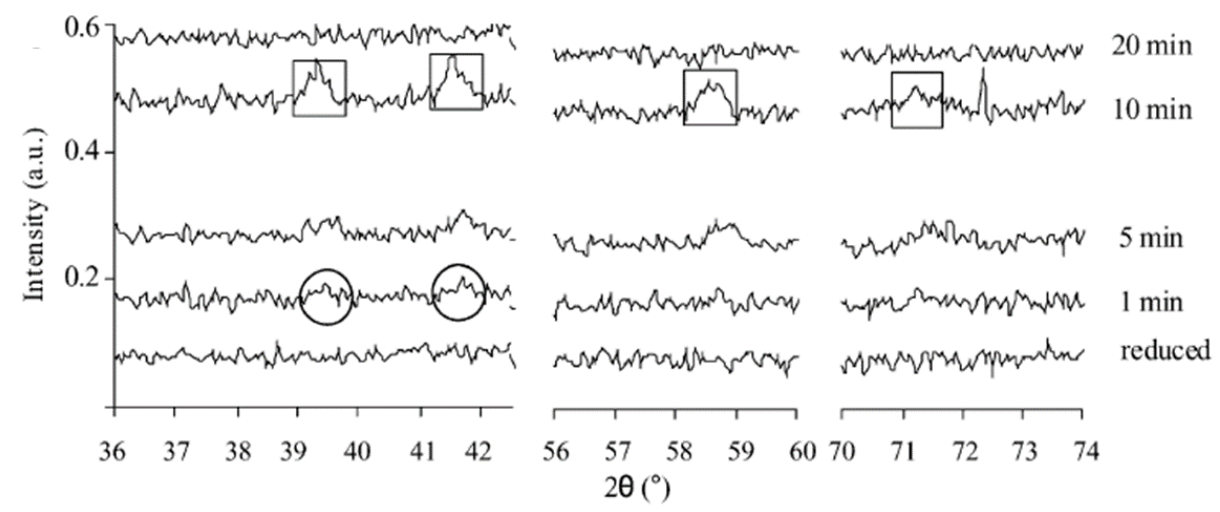

Figure. $13 \mathrm{Ni}_{3} \mathrm{C}$ X-Ray diffraction patterns on $\mathrm{Ni}$ foams (reduced at $700{ }^{\circ} \mathrm{C}$ ) after exposure to $25 \% \mathrm{C}_{2} \mathrm{H}_{4}$ in $\mathrm{N}_{2}$ (total flow rate $107 \mathrm{~mL} / \mathrm{min}$ ) at $450{ }^{\circ} \mathrm{C}$ during 0,10 to $20 \mathrm{~min}$. 


\subsection{Kinetics of carbon deposition on Ni-YSZ catalyst}

\subsubsection{Methane steam reforming kinetics}

Although we can intentionally prevent the coke formation by running the catalytic steam methane reforming reaction at regions where coke can be thermodynamically eliminated, kinetic restrictions can still lead to carbon deposition on the surface of catalyst. Before addressing the carbon deposition kinetics on Ni-YSZ catalyst, the kinetics of methane steam reforming have to be discussed.

Temkin et al.[51] proposed one of the early accurate kinetic model on methane steam reforming in 1979. He conducted the experiments on nickel foil at atmospheric pressure and changed the temperature from $470-900^{\circ} \mathrm{C}$. The results of the tests showed that the reforming reaction followed a first-order kinetic reaction and now there is a general agreement on this issue[52]. Later, Xu and Froment[53, 54] improved the Temkin's model and developed the most popular kinetic model for methane steam reaction. They provided a series of reactions and then reduced to three main reactions by considering LangmuirHinshelwood reaction mechanism, which was a commonly used approximation when dealing with complicated reactions[55]. The key assumption of the Langmuir-Hinshelwood mechanism is that the methane molecules, and $\mathrm{C}$ and $\mathrm{H}$ atoms were adsorbed onto the same sites. Therefore, the decomposition of one methane molecule requires five adsorption sites[56]. The proposed rate reaction expressions are shown in Equation (16)-(18) as for the reaction (19)-(21), where ki are the coefficient of reactions, Ki adsorption constants and Keq,i equilibrium constant of reactions[57].

$$
\mathrm{r}_{1}=\frac{\frac{\mathrm{k}_{1}}{\mathrm{p}_{\mathrm{H}_{2}}^{2.5}} \cdot\left[\mathrm{p}_{\mathrm{CH}_{4}} \cdot \mathrm{p}_{\mathrm{H}_{2} \mathrm{O}}-\frac{\mathrm{p}_{\mathrm{H}_{2}}^{3} \cdot \mathrm{p}_{\mathrm{CO}}}{\mathrm{K}_{\mathrm{eq} 1}}\right]}{\left(1+\mathrm{K}_{\mathrm{CO}} \cdot \mathrm{p}_{\mathrm{CO}}+\mathrm{K}_{\mathrm{H}_{2}} \cdot \mathrm{p}_{\mathrm{H}_{2}}+\mathrm{K}_{\mathrm{CH}_{4}} \cdot \mathrm{p}_{\mathrm{CH}_{4}}+\mathrm{K}_{\mathrm{H}_{2} \mathrm{O}} \cdot \frac{\mathrm{p}_{\mathrm{H}_{2} \mathrm{O}}}{\mathrm{p}_{\mathrm{H}_{2}}}\right)^{2}}
$$




$$
\begin{gathered}
\mathrm{r}_{2}=\frac{\frac{\mathrm{k}_{2}}{\mathrm{p}_{\mathrm{H}_{2}}} \cdot\left[\mathrm{p}_{\mathrm{CO}} \cdot \mathrm{p}_{\mathrm{H}_{2} \mathrm{O}}-\frac{\mathrm{p}_{\mathrm{H}_{2}} \cdot \mathrm{p}_{\mathrm{CO}_{2}}}{\mathrm{~K}_{\mathrm{eq} 2}}\right]}{\left(1+\mathrm{K}_{\mathrm{CO}} \cdot \mathrm{p}_{\mathrm{CO}}+\mathrm{K}_{\mathrm{H}_{2}} \cdot \mathrm{p}_{\mathrm{H}_{2}}+\mathrm{K}_{\mathrm{CH}_{4}} \cdot \mathrm{p}_{\mathrm{CH}_{4}}+\mathrm{K}_{\mathrm{H}_{2} \mathrm{O}} \cdot \frac{\mathrm{p}_{2} \mathrm{O}}{\mathrm{p}_{2}}\right)^{2}} \\
\mathrm{r}_{3}=\frac{\frac{\mathrm{k}_{3}}{\mathrm{p}_{\mathrm{H}_{2}}^{3.5}} \cdot\left[\mathrm{p}_{\mathrm{CH}_{4}} \cdot \mathrm{p}_{\mathrm{H}_{2} \mathrm{O}}^{2}-\frac{\mathrm{p}_{\mathrm{H}_{2}}^{4} \cdot \mathrm{p}_{\mathrm{CO}_{2}}}{\mathrm{~K}_{\mathrm{eq} 3}}\right]}{\left(1+\mathrm{K}_{\mathrm{CO}} \cdot \mathrm{p}_{\mathrm{CO}}+\mathrm{K}_{\mathrm{H}_{2}} \cdot \mathrm{p}_{\mathrm{H}_{2}}+\mathrm{K}_{\mathrm{CH}_{4}} \cdot \mathrm{p}_{\mathrm{CH}_{4}}+\mathrm{K}_{\mathrm{H}_{2} \mathrm{O}} \cdot \frac{\mathrm{p}_{\mathrm{H}_{2} \mathrm{O}}}{\mathrm{p}_{\mathrm{H}_{2}}}\right)^{2}} \\
\mathrm{CH}+\mathrm{H}_{2} \mathrm{O} \leftrightarrow{\mathrm{CO}+3 H_{2}}_{\mathrm{CO}+\mathrm{H}_{2} \mathrm{O} \leftrightarrow \mathrm{CO}_{2}+\mathrm{H}_{2}}^{(19)} \\
\mathrm{CH}+2 \mathrm{H}_{2} \mathrm{O} \leftrightarrow \mathrm{CO}_{2}+4 \mathrm{H}_{2}
\end{gathered}
$$

Ethan S. Hecht et al.[58] reported investigations of thermal methane reforming chemistry within porous Ni-YSZ anode materials. Table.5 lists a reaction mechanism which used to describe the heterogeneous kinetics within a Ni-YSZ anode. It represented all the global processes in the SOFC anode including methane steam reforming, water-gas-shift and surface carbon coverage. The net activation energy of reactions 12, 20, 21, and 23 depend on the $\mathrm{CO}(\mathrm{s})$ coverage as shown in Equation (22)[59], where $\mathrm{A}$ is a constant decided by reaction and $\theta_{\operatorname{cov}}$ is the available vacancies for the reactions.

$$
k=A T^{n} \exp \left(-\frac{E}{R T}\right) \exp \left(-\frac{\varepsilon_{\operatorname{cov}} \theta_{c o v}}{R T}\right)
$$

In summary, many studies have been investigated methane steam reforming kinetic by analyzing different catalysts and supports. They proposed different kinetic expressions by assuming different rate limiting steps for elementary reactions. According to Jones et al. [60], the differences in kinetics mechanisms are caused by the different distribution of particle sizes, metal particles dispersion, and support used in each study. 
Table.5[51] Heterogeneous reaction mechanism for $\mathrm{CH}_{4}$ reforming on Ni-based catalysts

\begin{tabular}{|c|c|c|c|c|}
\hline & Reaction & $A^{a}$ & $n$ & $E^{\mathrm{a}}$ \\
\hline 1. & $\mathrm{H}_{2}+\mathrm{Ni}(\mathrm{s})+\mathrm{Ni}(\mathrm{s}) \rightarrow \mathrm{H}(\mathrm{s})+\mathrm{H}(\mathrm{s})$ & $1.000 \times 10^{-02 \mathrm{~b}}$ & 0.0 & 0.00 \\
\hline 2. & $\mathrm{H}(\mathrm{s})+\mathrm{H}(\mathrm{s}) \rightarrow \mathrm{Ni}(\mathrm{s})+\mathrm{Ni}(\mathrm{s})+\mathrm{H}_{2}$ & $5.593 \times 10^{+19}$ & 0.0 & 88.12 \\
\hline 3. & $\mathrm{O}_{2}+\mathrm{Ni}(\mathrm{s})+\mathrm{Ni}(\mathrm{s}) \rightarrow \mathrm{O}(\mathrm{s})+\mathrm{O}(\mathrm{s})$ & $1.000 \times 10^{-02 \mathrm{~b}}$ & 0.0 & 0.00 \\
\hline 4. & $\mathrm{O}(\mathrm{s})+\mathrm{O}(\mathrm{s}) \rightarrow \mathrm{Ni}(\mathrm{s})+\mathrm{Ni}(\mathrm{s})+\mathrm{O}_{2}$ & $2.508 \times 10^{+23}$ & 0.0 & 470.39 \\
\hline 5. & $\mathrm{CH}_{4}+\mathrm{Ni}(\mathrm{s}) \rightarrow \mathrm{CH}_{4}(\mathrm{~s})$ & $8.000 \times 10^{-03 \mathrm{~b}}$ & 0.0 & 0.00 \\
\hline 6. & $\mathrm{CH}_{4}(\mathrm{~s}) \rightarrow \mathrm{Ni}(\mathrm{s})+\mathrm{CH}_{4}$ & $5.302 \times 10^{+15}$ & 0.0 & 33.15 \\
\hline 7. & $\mathrm{H}_{2} \mathrm{O}+\mathrm{Ni}(\mathrm{s}) \rightarrow \mathrm{H}_{2} \mathrm{O}(\mathrm{s})$ & $1.000 \times 10^{-01 ~ b}$ & 0.0 & 0.00 \\
\hline 8. & $\mathrm{H}_{2} \mathrm{O}(\mathrm{s}) \rightarrow \mathrm{Ni}(\mathrm{s})+\mathrm{H}_{2} \mathrm{O}$ & $4.579 \times 10^{+12}$ & 0.0 & 62.68 \\
\hline 9. & $\mathrm{CO}_{2}+\mathrm{Ni}(\mathrm{s}) \rightarrow \mathrm{CO}_{2}(\mathrm{~s})$ & $1.000 \times 10^{-05 b}$ & 0.0 & 0.00 \\
\hline 10. & $\mathrm{CO}_{2}(\mathrm{~s}) \rightarrow \mathrm{Ni}(\mathrm{s})+\mathrm{CO}_{2}$ & $9.334 \times 10^{+07}$ & 0.0 & 28.80 \\
\hline 11. & $\mathrm{CO}+\mathrm{Ni}(\mathrm{s}) \rightarrow \mathrm{CO}(\mathrm{s})$ & $5.000 \times 10^{-01 \mathrm{~b}}$ & 0.0 & 0.00 \\
\hline \multirow[t]{2}{*}{12.} & $\mathrm{CO}(\mathrm{s}) \rightarrow \mathrm{Ni}(\mathrm{s})+\mathrm{CO}$ & $4.041 \times 10^{+11}$ & 0.0 & 112.85 \\
\hline & & $8 \mathrm{CO}(\mathrm{s})$ & & $-50.0^{\circ}$ \\
\hline 13. & $\mathrm{O}(\mathrm{s})+\mathrm{H}(\mathrm{s}) \rightarrow \mathrm{OH}(\mathrm{s})+\mathrm{Ni}(\mathrm{s})$ & $5.000 \times 10^{+22}$ & 0.0 & 97.90 \\
\hline 14. & $\mathrm{OH}(\mathrm{s})+\mathrm{Ni}(\mathrm{s}) \rightarrow \mathrm{O}(\mathrm{s})+\mathrm{H}(\mathrm{s})$ & $2.005 \times 10^{+21}$ & 0.0 & 37.19 \\
\hline 15. & $\mathrm{OH}(\mathrm{s})+\mathrm{H}(\mathrm{s}) \rightarrow \mathrm{H}_{2} \mathrm{O}(\mathrm{s})+\mathrm{Ni}(\mathrm{s})$ & $3.000 \times 10^{+20}$ & 0.0 & 42.70 \\
\hline 16. & $\mathrm{H}_{2} \mathrm{O}(\mathrm{s})+\mathrm{Ni}(\mathrm{s}) \rightarrow \mathrm{OH}(\mathrm{s})+\mathrm{H}(\mathrm{s})$ & $2.175 \times 10^{+21}$ & 0.0 & 91.36 \\
\hline 17. & $\mathrm{OH}(\mathrm{s})+\mathrm{OH}(\mathrm{s}) \rightarrow \mathrm{O}(\mathrm{s})+\mathrm{H}_{2} \mathrm{O}(\mathrm{s})$ & $3.000 \times 10^{+21}$ & 0.0 & 100.00 \\
\hline 18. & $\mathrm{O}(\mathrm{s})+\mathrm{H}_{2} \mathrm{O}(\mathrm{s}) \rightarrow \mathrm{OH}(\mathrm{s})+\mathrm{OH}(\mathrm{s})$ & $5.423 \times 10^{+23}$ & 0.0 & 209.37 \\
\hline 19. & $\mathrm{O}(\mathrm{s})+\mathrm{C}(\mathrm{s}) \rightarrow \mathrm{CO}(\mathrm{s})+\mathrm{Ni}(\mathrm{s})$ & $5.200 \times 10^{+23}$ & 0.0 & 148.10 \\
\hline \multirow[t]{2}{*}{20.} & $\mathrm{CO}(\mathrm{s})+\mathrm{Ni}(\mathrm{s}) \rightarrow \mathrm{O}(\mathrm{s})+\mathrm{C}(\mathrm{s})$ & $1.418 \times 10^{+22}$ & -3.0 & 115.97 \\
\hline & & $8 \mathrm{CO}(\mathrm{s})$ & & $-50.0^{\circ}$ \\
\hline \multirow[t]{2}{*}{21.} & $\mathrm{O}(\mathrm{s})+\mathrm{CO}(\mathrm{s}) \rightarrow \mathrm{CO}_{2}(\mathrm{~s})+\mathrm{Ni}(\mathrm{s})$ & $2.000 \times 10^{+19}$ & 0.0 & 123.60 \\
\hline & & $\mathrm{COO}(\mathrm{s})$ & & $-50.0^{\circ}$ \\
\hline 22. & $\mathrm{CO}_{2}(\mathrm{~s})+\mathrm{Ni}(\mathrm{s}) \rightarrow \mathrm{O}(\mathrm{s})+\mathrm{CO}(\mathrm{s})$ & $3.214 \times 10^{+23}$ & -1.0 & 86.50 \\
\hline \multirow[t]{2}{*}{23.} & $\mathrm{HCO}(\mathrm{s})+\mathrm{Ni}(\mathrm{s}) \rightarrow \mathrm{CO}(\mathrm{s})+\mathrm{H}(\mathrm{s})$ & $3.700 \times 10^{+21}$ & 0.0 & 0.0 \\
\hline & & ${ }^{\mathrm{CO}(\mathrm{s})}$ & & $50.0^{6}$ \\
\hline 24. & $\mathrm{CO}(\mathrm{s})+\mathrm{H}(\mathrm{s}) \rightarrow \mathrm{HCO}(\mathrm{s})+\mathrm{Ni}(\mathrm{s})$ & $2.338 \times 10^{+20}$ & -1.0 & 127.98 \\
\hline 25. & $\mathrm{HCO}(\mathrm{s})+\mathrm{Ni}(\mathrm{s}) \rightarrow \mathrm{O}(\mathrm{s})+\mathrm{CH}(\mathrm{s})$ & $3.700 \times 10^{+24}$ & -3.0 & 95.80 \\
\hline 26. & $\mathrm{O}(\mathrm{s})+\mathrm{CH}(\mathrm{s}) \rightarrow \mathrm{HCO}(\mathrm{s})+\mathrm{Ni}(\mathrm{s})$ & $7.914 \times 10^{+20}$ & 0.0 & 114.22 \\
\hline 27. & $\mathrm{CH}_{4}(\mathrm{~s})+\mathrm{Ni}(\mathrm{s}) \rightarrow \mathrm{CH}_{3}(\mathrm{~s})+\mathrm{H}(\mathrm{s})$ & $3.700 \times 10^{+21}$ & 0.0 & 57.70 \\
\hline 28. & $\mathrm{CH}_{3}(\mathrm{~s})+\mathrm{H}(\mathrm{s}) \rightarrow \mathrm{CH}_{4}(\mathrm{~s})+\mathrm{Ni}(\mathrm{s})$ & $4.438 \times 10^{+21}$ & 0.0 & 58.83 \\
\hline 29. & $\mathrm{CH}_{3}(\mathrm{~s})+\mathrm{Ni}(\mathrm{s}) \rightarrow \mathrm{CH}_{2}(\mathrm{~s})+\mathrm{H}(\mathrm{s})$ & $3.700 \times 10^{+24}$ & 0.0 & 100.00 \\
\hline 30. & $\mathrm{CH}_{2}(\mathrm{~s})+\mathrm{H}(\mathrm{s}) \rightarrow \mathrm{CH}_{3}(\mathrm{~s})+\mathrm{Ni}(\mathrm{s})$ & $9.513 \times 10^{+22}$ & 0.0 & 52.58 \\
\hline 31. & $\mathrm{CH}_{2}(\mathrm{~s})+\mathrm{Ni}(\mathrm{s}) \rightarrow \mathrm{CH}(\mathrm{s})+\mathrm{H}(\mathrm{s})$ & $3.700 \times 10^{+24}$ & 0.0 & 97.10 \\
\hline 32. & $\mathrm{CH}(\mathrm{s})+\mathrm{H}(\mathrm{s}) \rightarrow \mathrm{CH}_{2}(\mathrm{~s})+\mathrm{Ni}(\mathrm{s})$ & $3.008 \times 10^{+24}$ & 0.0 & 76.43 \\
\hline 33. & $\mathrm{CH}(\mathrm{s})+\mathrm{Ni}(\mathrm{s}) \rightarrow \mathrm{C}(\mathrm{s})+\mathrm{H}(\mathrm{s})$ & $3.700 \times 10^{+21}$ & 0.0 & 18.80 \\
\hline 34. & $\mathrm{C}(\mathrm{s})+\mathrm{H}(\mathrm{s}) \rightarrow \mathrm{CH}(\mathrm{s})+\mathrm{Ni}(\mathrm{s})$ & $4.400 \times 10^{+22}$ & 0.0 & 160.49 \\
\hline 35. & $\mathrm{O}(\mathrm{s})+\mathrm{CH}_{4}(\mathrm{~s}) \rightarrow \mathrm{CH}_{3}(\mathrm{~s})+\mathrm{OH}(\mathrm{s})$ & $1.700 \times 10^{+24}$ & 0.0 & 88.30 \\
\hline 36. & $\mathrm{CH}_{3}(\mathrm{~s})+\mathrm{OH}(\mathrm{s}) \rightarrow \mathrm{O}(\mathrm{s})+\mathrm{CH}_{4}(\mathrm{~s})$ & $8.178 \times 10^{+22}$ & 0.0 & 28.72 \\
\hline 37. & $\mathrm{O}(\mathrm{s})+\mathrm{CH}_{3}(\mathrm{~s}) \rightarrow \mathrm{CH}_{2}(\mathrm{~s})+\mathrm{OH}(\mathrm{s})$ & $3.700 \times 10^{+24}$ & 0.0 & 130.10 \\
\hline 38. & $\mathrm{CH}_{2}(\mathrm{~s})+\mathrm{OH}(\mathrm{s}) \rightarrow \mathrm{O}(\mathrm{s})+\mathrm{CH}_{3}(\mathrm{~s})$ & $3.815 \times 10^{+21}$ & 0.0 & 21.97 \\
\hline 39. & $\mathrm{O}(\mathrm{s})+\mathrm{CH}_{2}(\mathrm{~s}) \rightarrow \mathrm{CH}(\mathrm{s})+\mathrm{OH}(\mathrm{s})$ & $3.700 \times 10^{+24}$ & 0.0 & 126.80 \\
\hline 40. & $\mathrm{CH}(\mathrm{s})+\mathrm{OH}(\mathrm{s}) \rightarrow \mathrm{O}(\mathrm{s})+\mathrm{CH}_{2}(\mathrm{~s})$ & $1.206 \times 10^{+23}$ & 0.0 & 45.42 \\
\hline 41. & $\mathrm{O}(\mathrm{s})+\mathrm{CH}(\mathrm{s}) \rightarrow \mathrm{C}(\mathrm{s})+\mathrm{OH}(\mathrm{s})$ & $3.700 \times 10^{+21}$ & 0.0 & 48.10 \\
\hline 42 . & $\mathrm{C}(\mathrm{s})+\mathrm{OH}(\mathrm{s}) \rightarrow \mathrm{O}(\mathrm{s})+\mathrm{CH}(\mathrm{s})$ & $1.764 \times 10^{+21}$ & 0.0 & 129.08 \\
\hline
\end{tabular}

\footnotetext{
a Arrhenius parameters for the rate constants written in the form: $k=A T^{n} \exp (-E / R T)$. The units of $A$ are given in terms of moles, $\mathrm{cm}$, and s. $E$ is in $\mathrm{kJ} / \mathrm{mol}$.

${ }^{\mathrm{b}}$ Sticking coefficient.

${ }^{c}$ Coverage-dependent activation energy (see Eq. (11)). Total available surface site density is $\Gamma=2.60 \times 10^{-9} \mathrm{~mol} / \mathrm{cm}^{2}$.
}

\subsubsection{Kinetics of carbon deposition for methane steam reforming}

For methane steam reforming, there are mainly two pathways for carbon deposition, which are decomposition of methane and $\mathrm{CO}$ disproportionation (Boudouard reaction). The reaction equations have been shown in previous parts by Equation (2) and Equation (3). The coke can also be removed by carbon 
gasification, which is shown in Equation (4) as the reverse reaction. For Ni-YSZ anode material in solid oxide fuel cell, the diffusion of carbon through nickel particles can lead to the removal of surface carbon and this diffusion phenomenon can be regarded as one of the steps in the global mechanism of carbon filament formation and gasification[61]. The coupling of the surface reactions including methane cracking and $\mathrm{CO}$ disproportionation, the segregation process, and the diffusion of carbon through the nickel particle leads to a model of the process when we are dealing with carbon filament formation, which forms the basis for the kinetic modeling of carbon formation and gasification reactions.

The kinetic model of carbon deposition for methane steam reforming based on the elementary steps, which consists a rate-limiting dissociative chemisorption step and a stepwise dehydrogenation of the chemisorbed methyl group, was firstly suggested by Grabke and et.al [62-64]. They came to the conclusion that the first chemisorbed step of $\mathrm{CH} 4$ is the rate-limiting step. The elementary step of methane decomposition is shown in Table.6[65]. P.Fan and co-workers[66] further studied the carbon formation in a methane and hydrogen mixed atmosphere and calculated all the kinetic model by assuming each step was the rate-determining step. After running the experiments, they found that only the methane chemisorption step was verified to be the rate-limiting step.

Table.6[65] Mechanism of methane cracking starting with non-dissociative methane adsorption

\begin{aligned} $\mathrm{CH}_{4}+\mathrm{I}($ Vacant site $)=\mathrm{CH}_{4}(\mathrm{ad}) \\ \mathrm{CH}_{4}(\mathrm{ad})=\mathrm{CH}_{3}(\mathrm{ad})+\mathrm{H}(\mathrm{ad}) \\ \mathrm{CH}_{3}(\mathrm{ad})=\mathrm{CH}_{2}(\mathrm{ad})+\mathrm{H}(\mathrm{ad}) \\ \mathrm{CH}_{2}(\mathrm{ad})=\mathrm{CH}(\mathrm{ad})+\mathrm{H}(\mathrm{ad}) \\ \mathrm{CH}(\mathrm{ad})=\mathrm{C}(\mathrm{ad})+\mathrm{H}(\mathrm{ad}) \\ \mathrm{C}(\mathrm{ad})=\mathrm{C}($ dissolved $) \\ 2 \mathrm{H}(\mathrm{ad})=\mathrm{H}_{2}+2 \mathrm{I} \\$\hline\end{aligned}


J-W Snoeck and G.F.Froment proposed a kinetic model for Boudouard reaction in which adsorbed oxygen atoms act as intermediate, because these are known to be important in the mechanism of steam reforming and the water-gas shift reaction. The elementary steps of the reactions considered were shown in Table.7.

As widely known, carbon atoms can dissolve into the bulk of $\mathrm{Ni}$ particles. The diffusion phenomenon can be a crucial factor for coke formation. In terms of Fick's law, at steady state, the coking rate coming from the surface reaction equals the rate of carbon diffusion through Ni particles. The diffusion equation is written as:

$$
r=\frac{D_{C}}{d_{N i}} a_{N i}\left(C_{C_{N i}, f}-C_{C_{N i}, r}\right)
$$

Where $D_{C}$ is the effective diffusivity for carbon diffusion through the nickel particle, $d_{N i}$ is the effective diffusion length in $\mathrm{Ni}$ particle, $\mathrm{a}_{\mathrm{Ni}}$ is the specific surface area of $\mathrm{Ni}$ particles, $\mathrm{C}_{\mathrm{CNi}, \mathrm{f}}$ is the carbon concentration on the front side of the Ni particle, $\mathrm{C}_{\mathrm{CNi}, \mathrm{r}}$ is the carbon concentration on the rear side of the Ni particle.

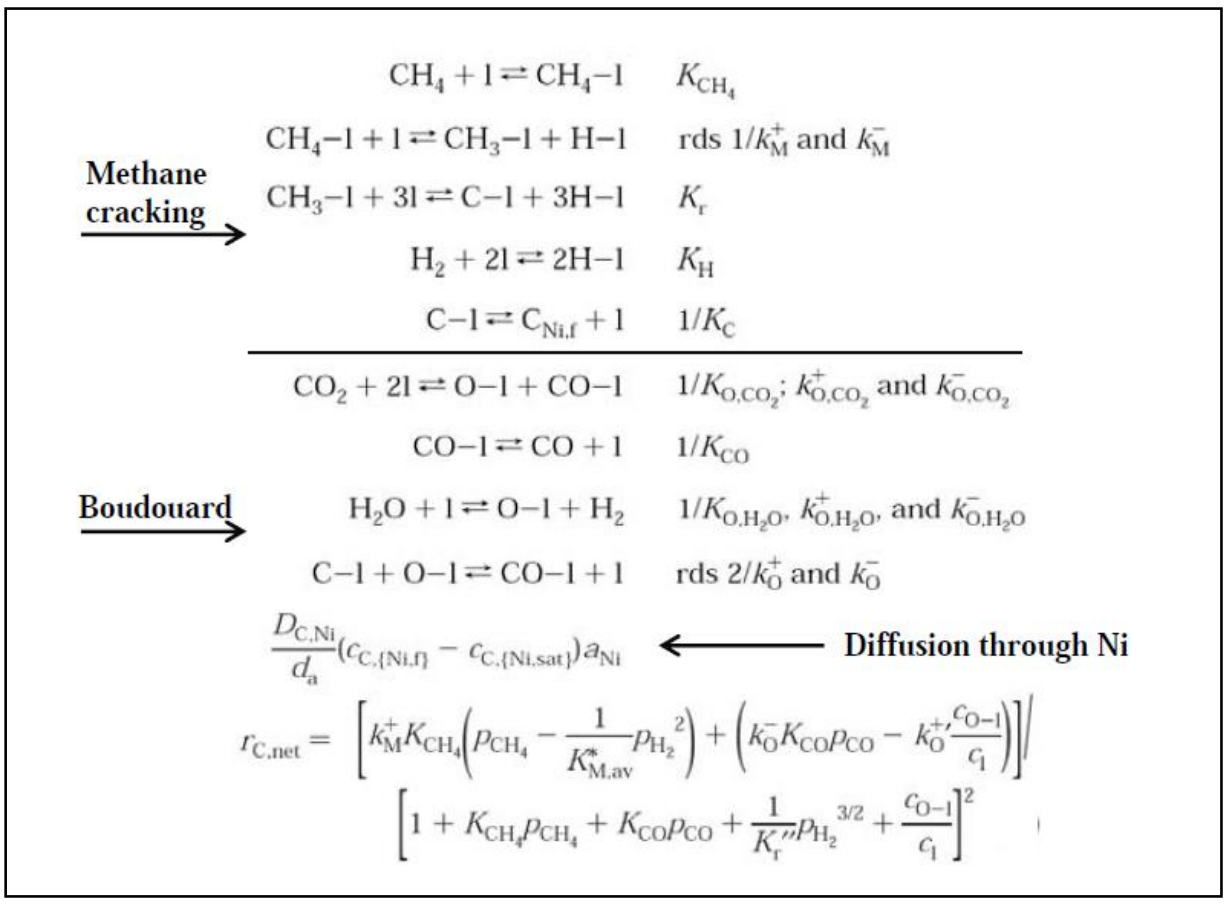


Figure.13 [55] Elementary steps of coke formation from methane cracking and of the gasification of coke by $\mathrm{H}_{2} \mathrm{O}$ and $\mathrm{H}_{2}$. Net rate equation for coke formation accounting also for diffusion of carbon through the $\mathrm{Ni}$ particles of catalyst.

Coupling Equation (23) with the rate equations for adsorption, Equation (24) for the chemical steps of the finally retained model can be obtained and shown:

$$
r_{\mathrm{C}, \mathrm{B}}=\frac{k_{\mathrm{B}}^{+} K_{\mathrm{CO}} p_{\mathrm{CO}}-\frac{k_{\mathrm{B}}^{-} K_{\mathrm{C}} c_{\mathrm{C},\{\mathrm{Ni}, \mathrm{f}\}}}{K_{\mathrm{O}, \mathrm{CO}} K_{\mathrm{CO}}} \frac{p_{\mathrm{CO}_{2}}}{p_{\mathrm{CO}}}}{\left(1+K_{\mathrm{C}} c_{\mathrm{C},\{\mathrm{Ni}, \mathrm{f}\}}+K_{\mathrm{CO}} p_{\mathrm{CO}}+\frac{1}{K_{\mathrm{O}, \mathrm{CO}_{2}} K_{\mathrm{CO}}} \frac{p_{\mathrm{CO}_{2}}}{p_{\mathrm{CO}}}\right)^{2}}
$$

So when the surface reactions including methane cracking and $\mathrm{CO}$ disproportionation are considered, the segregation process, and the diffusion of carbon through the nickel particle as a whole, we can get a net rate equation for carbon formation, which is shown in Figure.13[55].

Table.7 [67] Kinetic model of elementary steps for Boudouard reaction and carbon diffusion

$$
\begin{aligned}
& \text { adsorption of } \mathrm{CO} \\
& \qquad \mathrm{CO}+\mathrm{l} \rightleftarrows \mathrm{CO}-\mathrm{l} \\
& \text { carbon formation } \\
& \qquad \begin{array}{l}
\mathrm{CO}-\mathrm{l}+\mathrm{l} \rightleftarrows \mathrm{C}-\mathrm{l}+\mathrm{O}-\mathrm{l} \\
\mathrm{CO}+2 \mathrm{l} \rightleftarrows \mathrm{C}-\mathrm{l}+\mathrm{O}-\mathrm{l}
\end{array}
\end{aligned}
$$

reaction of the $\mathrm{O}-\mathrm{l}$ intermediate

$$
\begin{aligned}
& \mathrm{O}-\mathrm{I}+\mathrm{CO}-\mathrm{l} \rightleftarrows \mathrm{CO}_{2}-\mathrm{l}+\mathrm{l} \\
& \mathrm{O}-\mathrm{l}+\mathrm{CO}-\mathrm{l} \rightleftarrows \mathrm{CO}_{2}+2 \mathrm{l} \\
& \mathrm{O}-\mathrm{l}+\mathrm{CO} \rightleftarrows \mathrm{CO}_{2}-\mathrm{l} \\
& \mathrm{O}-\mathrm{l}+\mathrm{CO} \rightleftarrows \mathrm{CO}_{2}+\mathrm{l}
\end{aligned}
$$

desorption of $\mathrm{CO}_{2}$

$$
\mathrm{CO}_{2} \mathrm{l} \rightleftarrows \mathrm{CO}_{2}+\mathrm{l}
$$

dissolution/segregation

$$
\mathrm{C}-\mathrm{l} \rightleftarrows \mathrm{C}_{\mathrm{Ni}, \mathrm{f}}+\mathrm{l}
$$

diffusion of carbon in nickel

$$
\mathrm{C}_{\mathrm{Ni}, \mathrm{f}} \rightarrow \mathrm{C}_{\mathrm{Ni}, \mathrm{r}}
$$

precipitation/dissolution of carbon

$$
\mathrm{C}_{\mathrm{Ni}, \mathrm{r}} \rightleftarrows \mathrm{C}_{\mathrm{w}}
$$




\subsection{Description of carbon deposition process on Ni particle}

Considering carbon formation mechanism as a whole, the one $[14,68,69]$ which is accepted most widely involves the following four steps[16]: a) hydrocarbon adsorption on the catalyst surface; b) conversion from the adsorbed hydrocarbon to absorbed carbon atoms by three reactions mentioned above (reactions (2) (3) and (4)) ; c) diffusion of carbon atoms through Ni particle boundaries and Ni bulk; d) precipitation on the rear side of the Ni particles. The whole process can be illustrated in Figure.14. As the carbon atoms precipitating on the rear side of the metal, the continuous growth of carbon nanofibers can lift the metal particles. This is the reason why we can observe Ni particles on the tips of carbon nanofibers in Figure.12 (d) (e) (f).

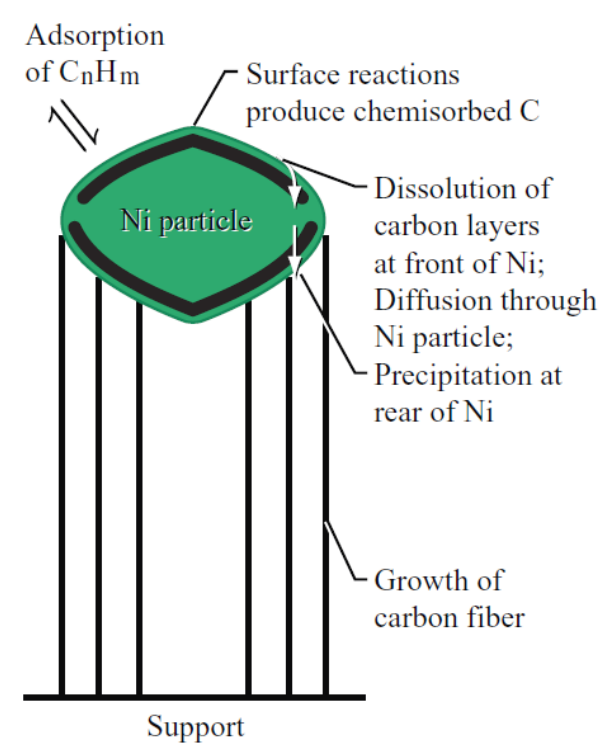

Figure.14 [16] Schematic representation of the catalytic growth of a carbon nanofiber (CNF) from a carboncontaining gas.

\section{Methods to suppress carbon deposition}

Carbon formation can greatly decrease the reforming efficiency and deactivate the whole reaction system by blocking the porous material structures of the anode side in solid oxide fuel cell. Many attempts have been made to overcome carbon deposit for methane steam reforming and great progresses have been 
achieved in the recent years. Generally speaking, many measures can be taken to confront the problem, which will be shown in below sections.

\subsection{Optimization of the reaction system parameters}

S. Rakass and co-workers [70] studied the $\mathrm{S}: \mathrm{C}$ of steam methane reforming using unsupported nickel powder catalysts and they also got similar results. Figure. 15 showed that within a quite wide temperature range, a higher steam to carbon would increase the methane conversion rate and a higher production rate of hydrogen.
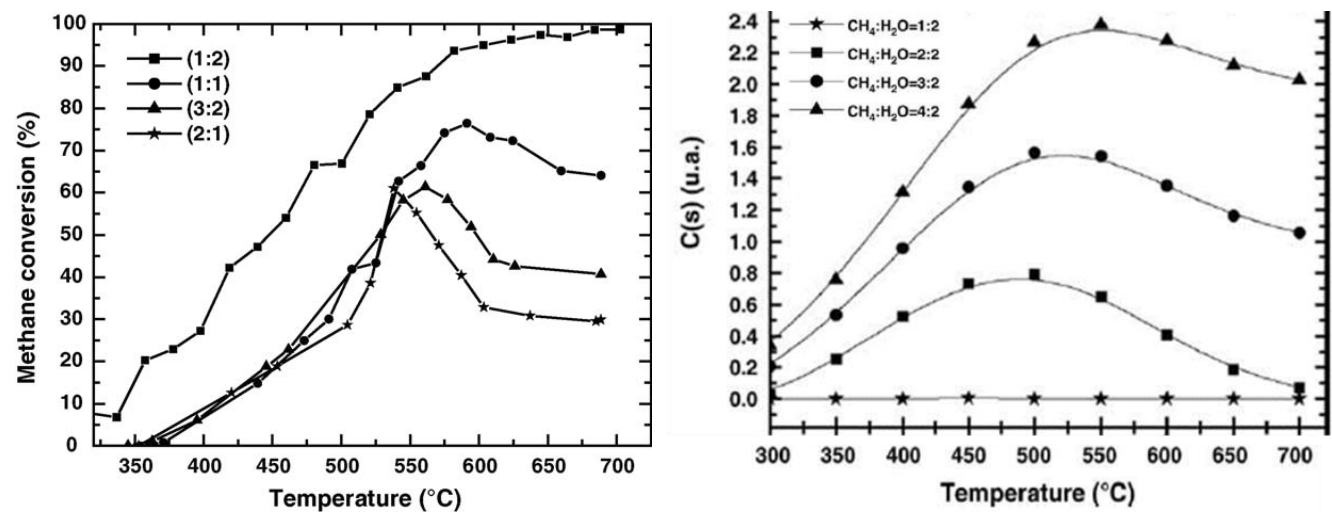

Figure.15 (a) methane conversion as function of $\mathrm{CH}_{4}: \mathrm{H}_{2} \mathrm{O}$ molar ratio and temperature

(b) $\mathrm{C}$ formation as function of $\mathrm{CH}_{4}: \mathrm{H}_{2} \mathrm{O}$ molar ratio and temperature

Some other researches $[71,72]$ also suggested that a higher steam to carbon ratio can dramatically decrease the carbon deposition on Ni-based anode material and make the whole system more stable and much more durable for long time service, which has been predicted by thermodynamic calculation shown in the previous section of this paper.

Also, by applying the calculation results from the thermodynamic view, coke favors low temperature and low pressure. So for practical application of solid oxide fuel cell with methane as the fuel, we can set up an optimized condition to suppress carbon deposition and enhance electrochemical reaction. 


\subsection{Metal elements or rare earth metal oxide addition}

Metal element or metal oxide addition is another great and effective way to suppress coking on $\mathrm{Ni}$ based anode materials for methane steam reforming. Alkali metal such as $\mathrm{K}, \mathrm{Ca}, \mathrm{Mg}$, and noble metal like $\mathrm{Ru}, \mathrm{Rh}$, and other metal elements like $\mathrm{Co}, \mathrm{Cu}$ can be impregnated into the system for the decrease of carbon formation of the system. Metal oxide containing rare earth elements like ceria has also been added into the methane steam reforming system because of its facilitated redox activity. The mechanism of preventing the coke presence for these elements are quite different, which will be presented in the following parts.

\subsubsection{Addition of metal oxides (promoters)}

A great number of oxides have been proposed as promoters for the catalysts to improve either the activity or the ability to prevent formation of coke. In recent years, researchers have shown growing interest in the effect of rare-earth oxide, especially the application of ceria $\left(\mathrm{CeO}_{2}\right)$, which is well known to have a sufficiently high oxygen storage capacity (OSC) to store oxygen under an oxidative atmosphere and release it under a reductive atmosphere[73]. In 2001, Nobuyoshi Nakagawa[74] found that the catalytic activity of $\mathrm{Ni}-\mathrm{YSZ}-\mathrm{CeO}_{2}$ anode was higher than that of Ni-YSZ, especially at low temperature. Then, it is reported[75] that for ethane and propane steam reforming, ceria doped $\mathrm{Ni} / \mathrm{Al}_{2} \mathrm{O}_{3}$ showed great reforming activity. The amount of carbon formation decreased with the increase of Ce composition. These improvements are mainly due to the influence of the redox propertied of doped ceria. The addition of ceria provided the oxygen vacancies which can adsorbed surface hydrocarbons $\left(\mathrm{C}_{\mathrm{n}} \mathrm{H}_{\mathrm{m}}+\mathrm{O}_{\mathrm{x}} \rightarrow \mathrm{nCO}+\mathrm{m} / 2\left(\mathrm{H}_{2}\right)+\mathrm{O}_{\mathrm{x}-\mathrm{m}}\right)$. Moreover, the formation of carbon via Boudard reaction can also be reduced because the carbon monoxide can react with the lattice oxygen to produce carbon dioxide, which acts as a depressor to Boudard reaction. Besides the studies on the amount of ceria added into the catalytic system, microstructure modification of $\mathrm{Ni}$ and ceria to enhance reforming reactivity has also been discovered. Chengxi Zhang and co-workers[76] fabricated $\mathrm{Ni}-\mathrm{CeO}_{2}$ catalysts for ethanol steam reforming via ball-milling process other than wet- 
impregnation method. The process and the stability test results can be briefly illustrated in Figure.16. Small nickel particles are anchored by $\mathrm{CeO}_{2}$ particles forming the core-like morphology and can remain its morphology after test. While, for conventional $\mathrm{Ni} / \mathrm{CeO}_{2}$ catalysts, $\mathrm{Ni}$ particles are adsorbed on the $\mathrm{CeO}_{2}$ surface randomly and have a coarsening problem after test. TEM images in Figure.17 clearly showed the influence of different fabrication methods of catalyst on the catalyst particle sizes and the amount of carbon deposition after test.

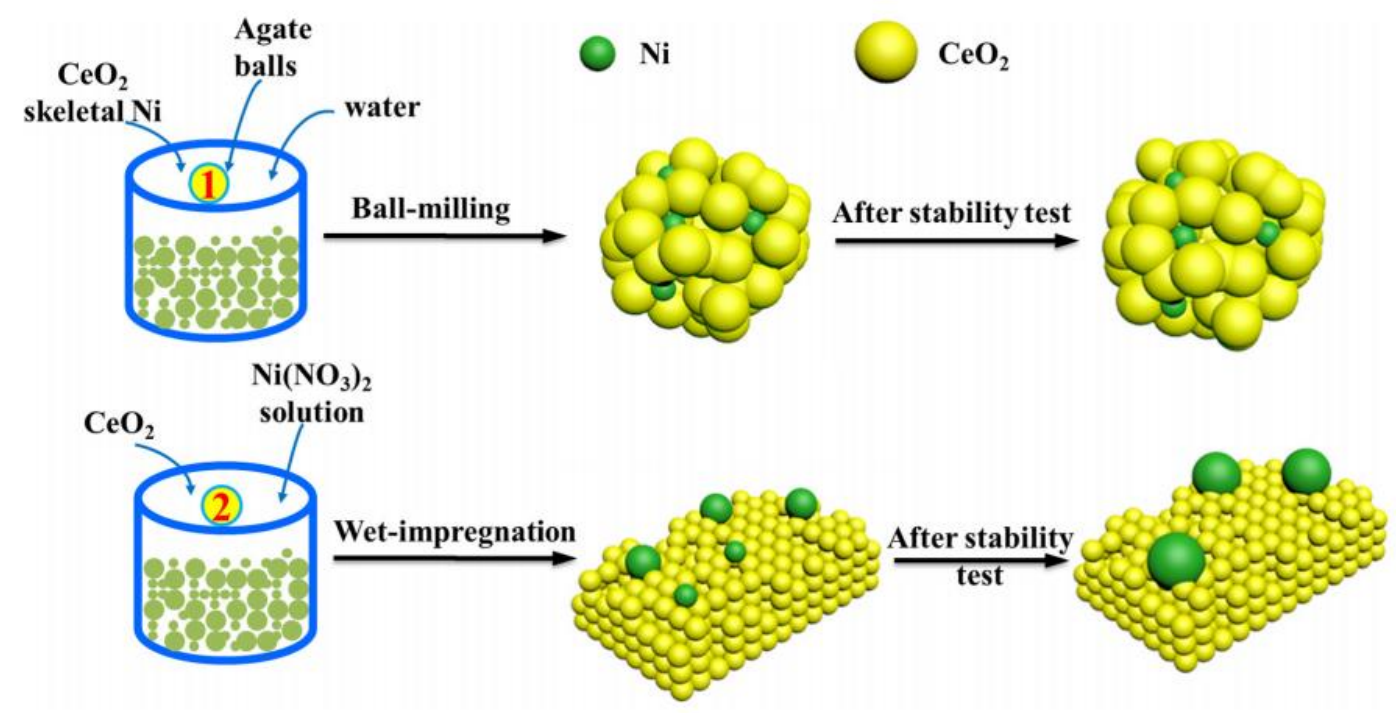

Figure.16[76] Schematic of structures of catalysts prepared by different methods 


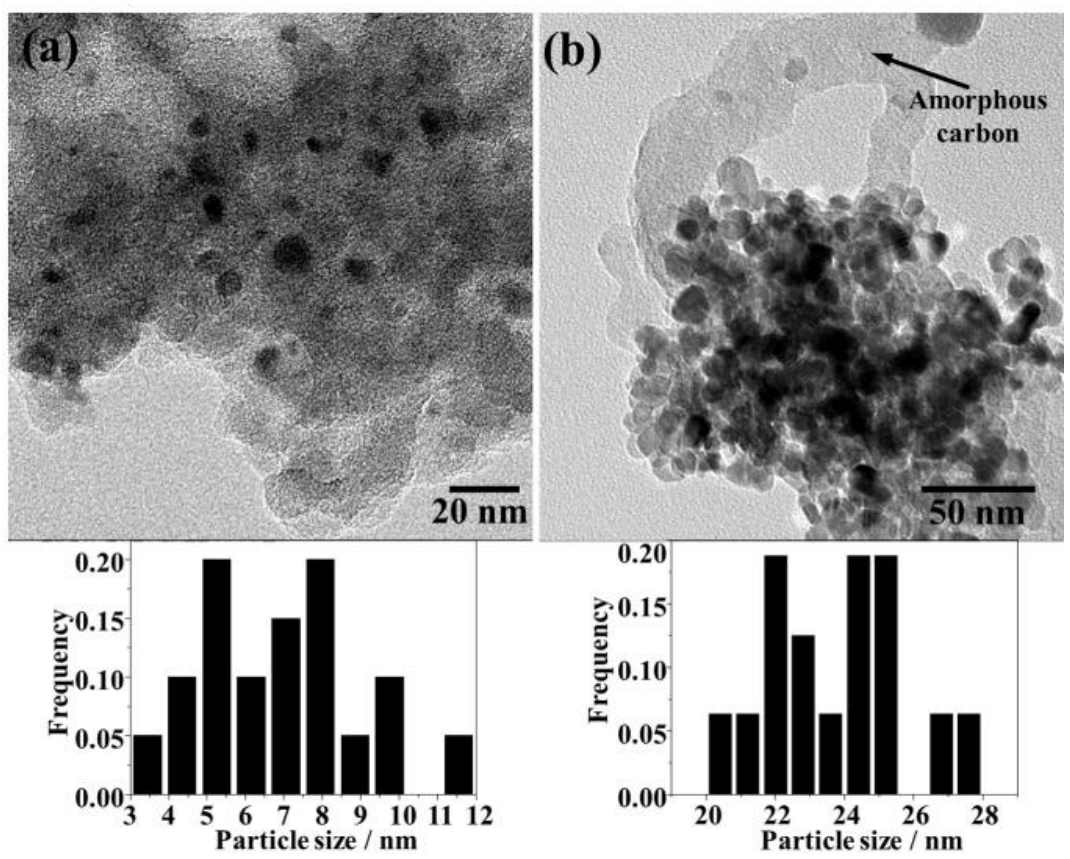

Figure.17[76] TEM images of the catalysts after stability test, (a) $\mathrm{Ni}-\mathrm{CeO}_{2}$ and (b) $\mathrm{Ni} / \mathrm{CeO}_{2}$

Carbon deposition on a catalyst is closely related to its surface acidity[77]. Alkaline earth oxides have been widely used as additives or as promoters in catalysts for the reforming reactions to neutralize the acidity of the aluminum oxide support[78, 79], especially for methane dry reforming . It has been found by BM Nagaraja [80] that the addition of $0.5 \mathrm{wt} \%$ potassium to catalyst can greatly improve both the activity and stability of the system. A. Carrero[81] and co-workers also indicated that $\mathrm{Mg}$ and Ca promoted catalysts favor the formation of defective carbon, which is much easier to be removed during the reforming process. Figure.18 contains three pictures of carbon nanofibers on three kinds of catalysts. It seems that the carbon fibers on $\mathrm{CuNi} / \mathrm{S}$ sample are much wider than those on $\mathrm{Mg}$ and $\mathrm{Ca}$ promoted catalysts, which indicates more carbon formation. The following TG analyses confirmed the deduction because a small peak was observed at $588^{\circ} \mathrm{C}$ for $\mathrm{CuNi} / \mathrm{S}$.

However, alkaline earth metal oxides are not suitable for steam reforming because of the risk of hydration of magnesia or calcium oxide[52]. The reaction may result in break-down of the catalyst because it expanses the molecular volume. For fuel cell applications, there are some strict restrictions for material 
selections. There are many characteristics of materials to consider, like redox stability, thermal expansion coefficient, sintering ability and so on. Alkaline earth oxides are weak on the match of thermal expansion coefficient with typically used electrolyte and also shows unstable redox stability in reducing atmosphere, which is the service condition as anode material for SOFC use. So despite the wide application in chemistry and chemical engineering, there is still a long way for the application in SOFC field unless a new connection is developed between the fuel cell support and the electrode.
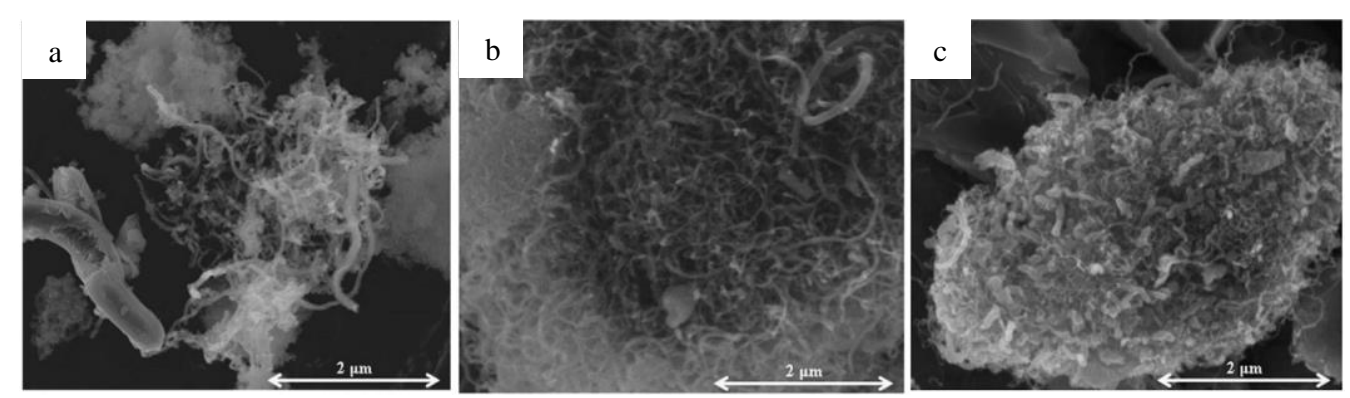

Figure.18 SEM images of used $\mathrm{Mg}$ and $\mathrm{Ca}$-modified $\mathrm{CuNi} / \mathrm{SiO}_{2}$ catalysts: (a) $\mathrm{CuNi} / \mathrm{S}$, (b)

CuNi/Mg20-S and (c) CuNi/Ca20-S

\subsubsection{Alloying effect by addition of other metal elements}

Ni-Co bimetallic system has long been studied [82-90] on different supports for methane fueled reforming because Co exhibited great activity for the reaction of methane decomposition, which is considered as the rate-determining step for methane reforming [91]. Ni-Co bimetallic catalysts are often prepared by co-precipitating method which using a common aqueous solution containing different amount of nickel nitrate and cobalt nitrate and comes with a calcination and reduction process. Some studies focused on Ni-Co bimetallic catalysts synthesized on traditional oxide support like alumina[89] or alumina modified support $[82,84]$. Besides traditional metal oxide support, Lin Chen and his co-workers[83] synthesized CoNi bimetallic aerogel catalysts by sol-gel method followed by the supercritical drying process. They took great advantages of the sol-gel catalysts, which exhibited high surface area (about $300 \mathrm{~m} 2 \mathrm{~g}-1$ ) and low

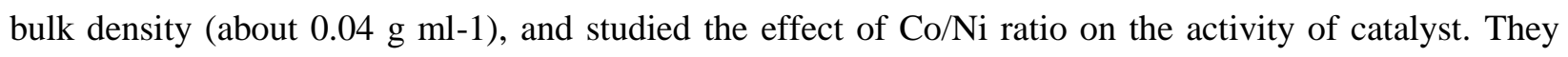
indicated that the metal particle size is smaller than the "critical size", leading to a strong coke resistance. 
Metal elements like $\mathrm{Cu}$ are also great candidates for the decrease of carbon deposition on Ni-based anode materials because of its low cost. Another great advantage of $\mathrm{Cu}$ is the high conductivity, which is of great benefit to serve as current collector of SOFC anode. H. Kim[92] and co-workers examined $\mathrm{Cu}-\mathrm{Ni}$ alloys as anode material for direct oxidation of methane in SOFC at 1073K. Figure.19 showed that the addition of $\mathrm{Cu}$ can greatly decrease the carbon formation on Ni-based anode cermet. Eon Woo Park [93] fabricated $\mathrm{Cu}-\mathrm{Ni}$-YSZ SOFC anode by electroplating $\mathrm{Cu}$ into a porous Ni-YSZ cermet anode and carbon deposited on the anode decreased dramatically at $700^{\circ} \mathrm{C}$, which indicated a great function of $\mathrm{Cu}$ addition in $\mathrm{Ni}$ particles for the decrease of carbon presence. They also found that $\mathrm{Cu}$ and $\mathrm{Ni}$ can form solid solution with different composition after heat treatment by XRD test shown in Figure.20. While, the power densities of $\mathrm{Cu}-\mathrm{Ni}$-YSZ anode-supported single cell in methane and hydrogen were lower than those of the Ni-YSZ. The reason is that $\mathrm{Cu}$ is a poor catalyst and the active sites on $\mathrm{Ni}$ surfaces were reduced due to the $\mathrm{Cu}$ alloying.

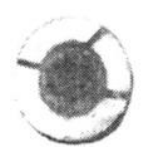

(a)

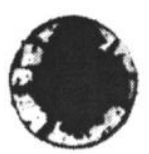

(d)

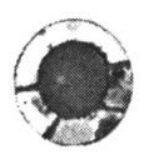

(b)

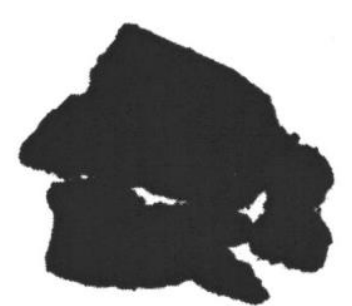

(e)

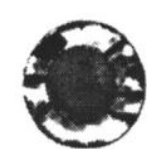

(c)

. 


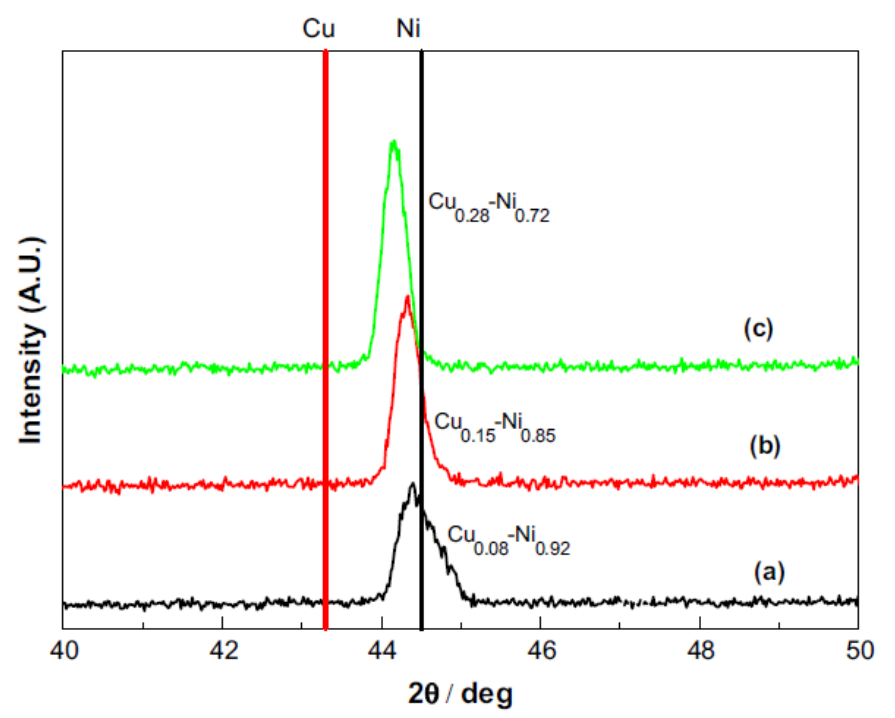

Figure.20 [93] XRD patterns of the Cu-electroplated Ni-YSZ anode, follow by heat-treatment at $700^{\circ} \mathrm{C}$ in hydrogen, depending on plating time: (a) $30 \mathrm{~min}$, (b) $1 \mathrm{~h}$ and (c) $3 \mathrm{~h}$

Another great selection to alloy with Ni to limit the carbon deposition on catalyst surface is $\mathrm{Sn}$. Sn$\mathrm{Ni}$ alloy catalysts are widely used in the steam reforming of methane and other hydrocarbons [94-96]. For example[96], Sn-Ni alloy (0.5-1wt\% nominal loading of Sn with respect to Ni) was prepared and exhibited improved tolerance to coke formation without compromising much of its electrochemical reactivity.

The SEM image and EDS test result are shown in Figure.21A, showing that $\mathrm{Sn}$ is mainly located on the surface layer of the particle. One of the big advantages of low Sn concentration in alloying metal is the tiny influence on the thermal expansion coefficient because the bulk material is still nickel, which can perfectly match to the commonly used electrolytes. Figure.21B is a clear evidence of the crucial role of $\mathrm{Sn}$ in preventing coke formation on the Ni catalyst surface. Carbon can be no longer observed by using line scan mode of EDS after Sn was coated on Ni. Figure.22 indicates that the activities of the two anode 
materials in the electrochemical oxidation of hydrogen are similar and the addition of tiny amount of $\mathrm{Sn}$ did not compromise much of the performance for the SOFC system.

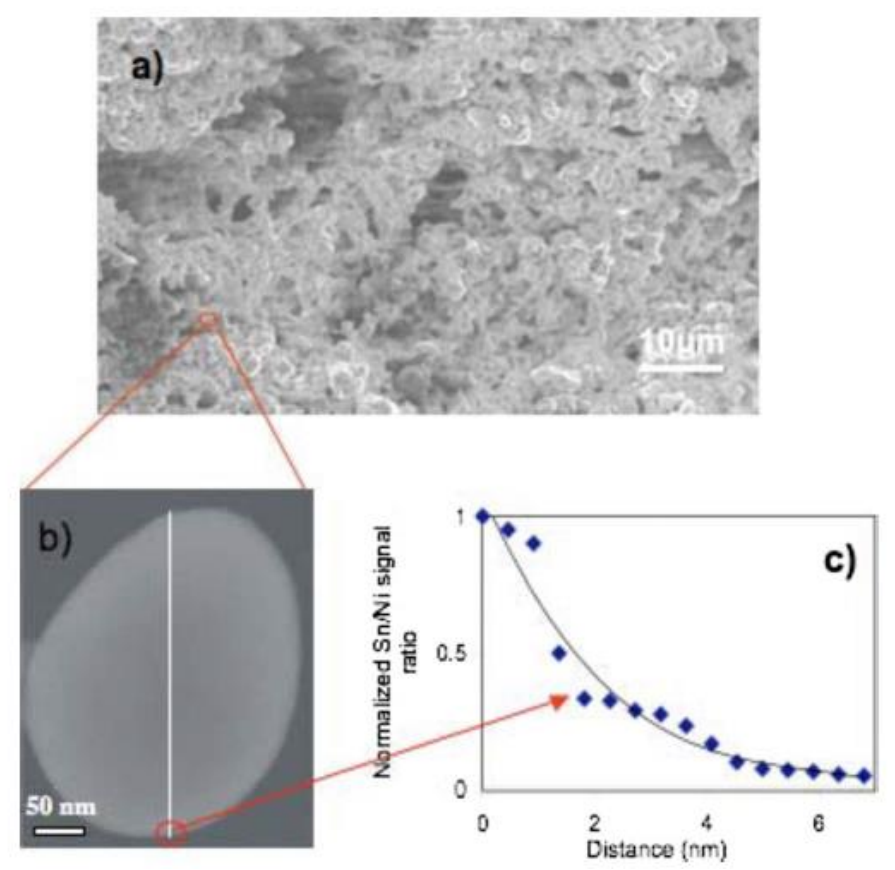

Figure.21A [96] (a) SEM image of a Sn/Ni anode (b) STEM image of a Sn/Ni particle (c) plot of the normalized $\mathrm{Sn} / \mathrm{Ni}$ ratio measured using EDS as a function of the distance from the bottom of the particle edge
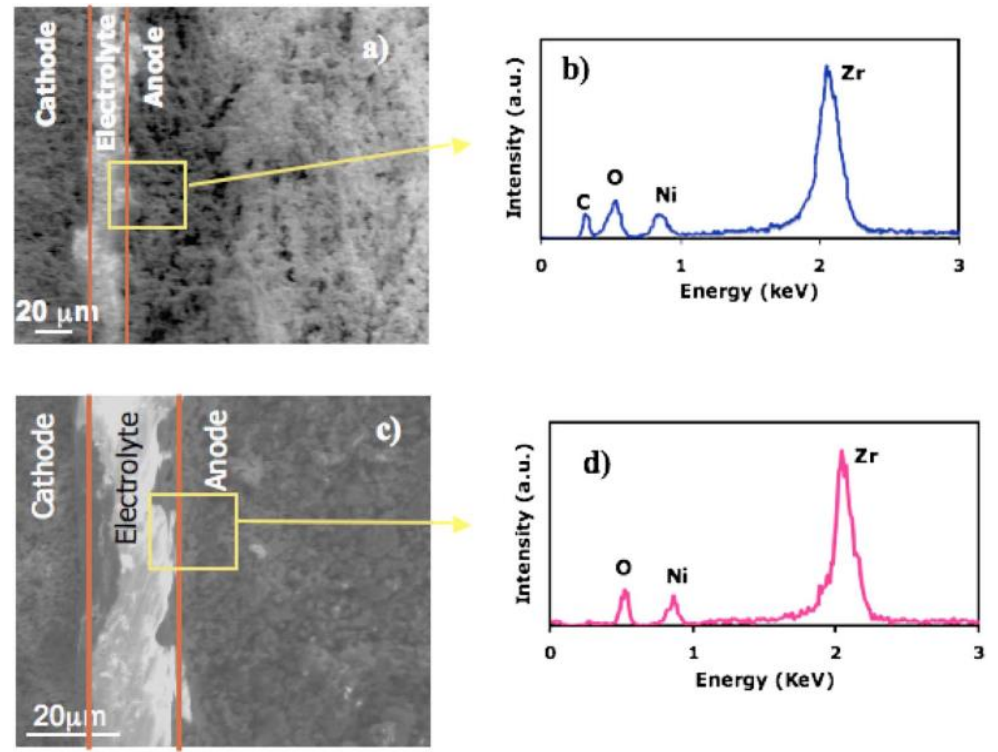
Figure.21B (Color online) (a) SEM of a cross section of Ni anode/electrolyte/cathode assembly after the electrochemical oxidation of isooctane at $1013 \mathrm{~K}$, (b)EDS elemental analysis of the region, outlined in (a), at the electrolyte/anode interface,(c) SEM of a cross section of Sn/Ni anode/electrolyte/cathode assembly after electrochemical oxidation of isooctane at $1013 \mathrm{~K}$, and (d) EDS elemental analysis of the region, outlined in (c) at the electrolyte/Sn/Ni anode interface.

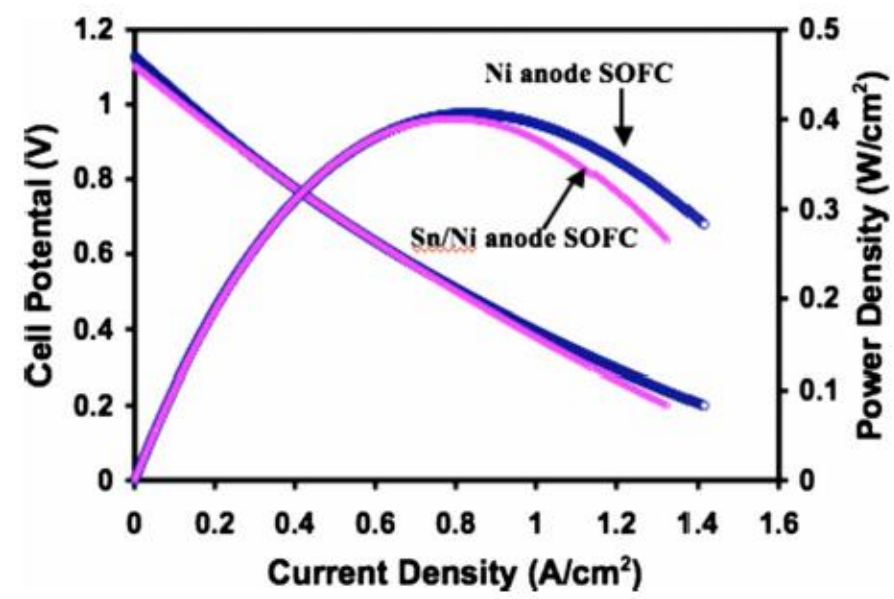

Figure.22 Plot of cell potential and power density as a function of current density for SOFCs with $\mathrm{Sn} / \mathrm{Ni}$ and $\mathrm{Ni}$ anodes. Operating conditions: humidified hydrogen/stagnant air, 1013K

\subsubsection{Addition of noble metal}

Noble metals like $\mathrm{Ru}$ and $\mathrm{Rh}$ are also excellent addition for suppressing carbon formation. Jin Hyeok Jeong [97] added small amount of $\mathrm{Ru}$ (wt 1\%) on Ni catalysts supported on $\mathrm{Al}_{2} \mathrm{O}_{3}$ or $\mathrm{MgAl}_{2} \mathrm{O}_{4}$ cermets and observed the suppression of carbon deposition on the anode. The presence of Ru in a highly dispersed state can also distribute the Ni particles evenly in the system, which decreased the particle size of Ni thus leading to a better coke resistance. Tatsuya Takeguchi et al.[98] applied various kinds of precious metals, which including $\mathrm{Ru}, \mathrm{Rh}, \mathrm{Pd}$ and $\mathrm{Pt}$, to the Ni-YSZ cermet system and studied the electrochemical activity as a SOFC anode and the carbon deposition. They found Ru, Pd, Pt can decrease carbon deposition rate and enhance the electrochemical property, shown in Figure.23. Rh can also promote electrochemical reaction, while the coke seemed to be more severe. However, the price of noble metal is so high that 
researchers from all over the world are seeking for alternatives to keep the price of catalyst low, which could benefit the wide use for industry in the future.

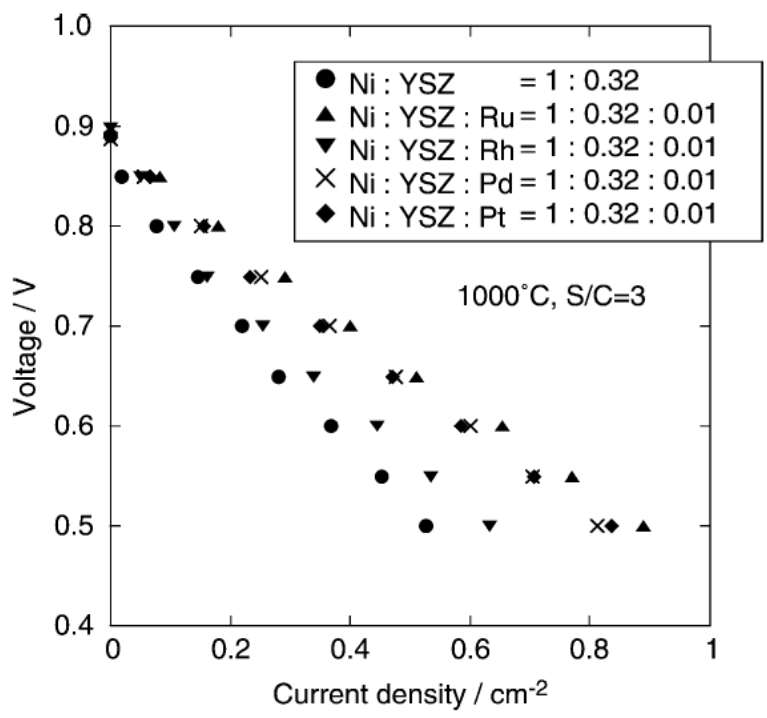

Figure.23 [98] Current-voltage characteristics in SOFC operation using precious metal-modified Ni-YSZ cermets at $1000^{\circ} \mathrm{C}$

\subsection{Nickel particle size optimization}

For Ni-based anode materials, the particle size of Ni can greatly influence the carbon formation. Researchers have done a lot of work on this problem and progresses have been made so far. KO Christensen[99] and co-workers have discovered that Ni particles which have a smaller crystal size have a higher resistance to coke formation. It is also proposed that there is a carbon thresholds for steam methane reforming on Ni catalyst for particular conditions. Figure.24 showed that in the conditions mentioned, carbon deposition will be totally eliminated if $\mathrm{Ni}$ crystal size is less than $10 \mathrm{~nm}$.

De Chen[14] studied the relations between the growth rate of carbon nanofibers and the sized $\mathrm{Ni}$ crystals, observing the optimum Ni particle size for the growth of carbon is around $34 \mathrm{~nm}$, which can be seen in Figure.25.

Actually, the reason why the addition of some metal elements into the Ni catalyst can suppress carbon formation is that the modified metal alloys have a better Ni crystal distribution and smaller $\mathrm{Ni}$ 
particle size. Jianguo Zhang[82] focused on the effects of Ni-Co content of the catalyst, attempting to avoid carbon formation on the catalyst. Figure. 26 showed the Ni particle distribution chart by adding different amount of Co into the alloy system and Figure.27 showed the carbon formation on the catalyst after $250 \mathrm{~h}$ test, which indicated that with a smaller size of Ni crystal size, coke can be greatly avoided in this condition.

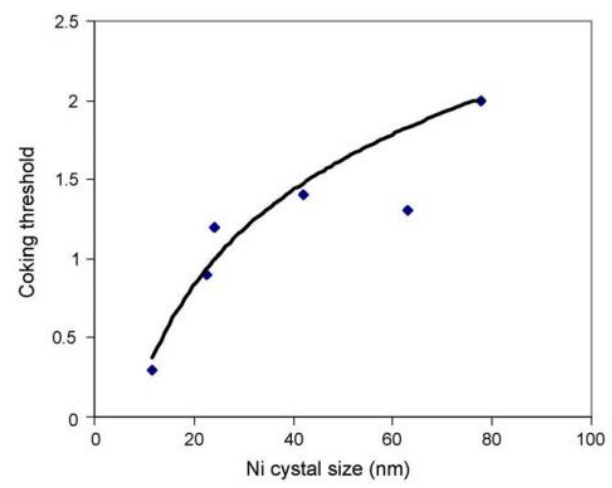

Figure.24 Carbon thresholds for steam methane reforming.

Conditions: total flow rate $=0.009 \mathrm{~mol} / \mathrm{min}, \mathrm{T}=823 \mathrm{~K}$ and $\mathrm{P}=20 \mathrm{bar}$.

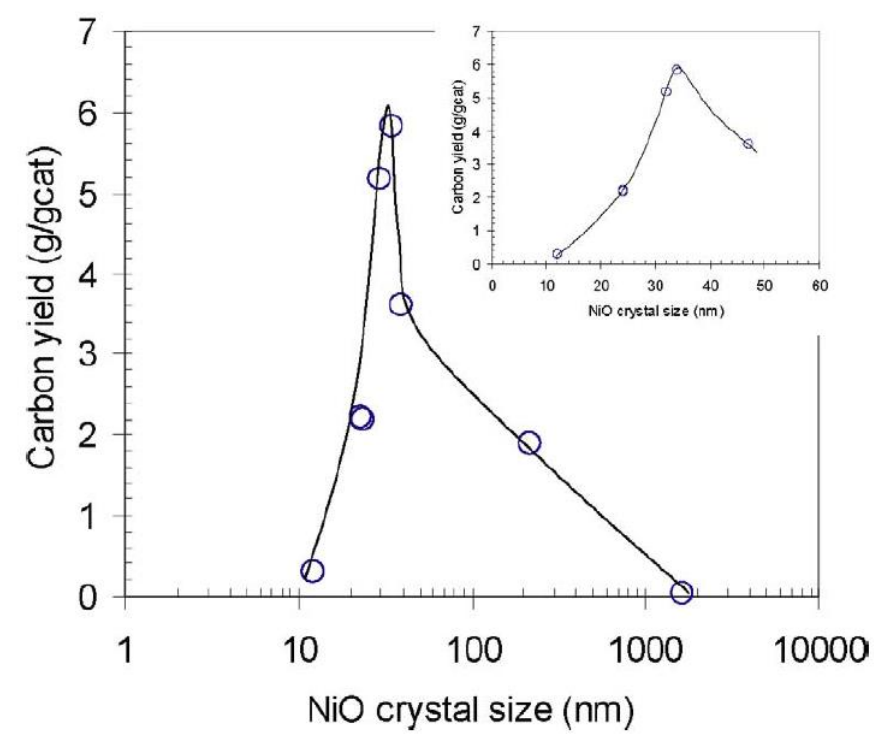

Figure.25 [14] Effects of $\mathrm{NiO}$ crystal size on the final carbon yield of carbon nanofiber 


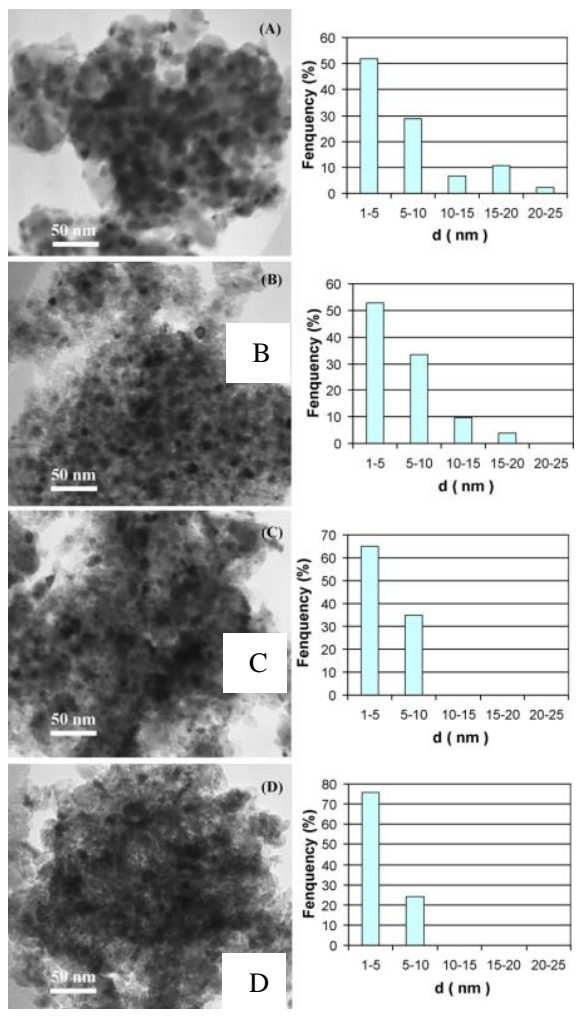

Figure.26 TEM images of Ni-Co catalysts with different metal content and particle size distribution before reaction. (A) $0.18 \mathrm{Ni0} .16 \mathrm{Co}$; (B) $0.06 \mathrm{Ni} 0.09 \mathrm{Co}$; (C) $0.04 \mathrm{Ni0} 0.05 \mathrm{Co}$; (D) $0.02 \mathrm{Ni0} 0.03 \mathrm{Co}$

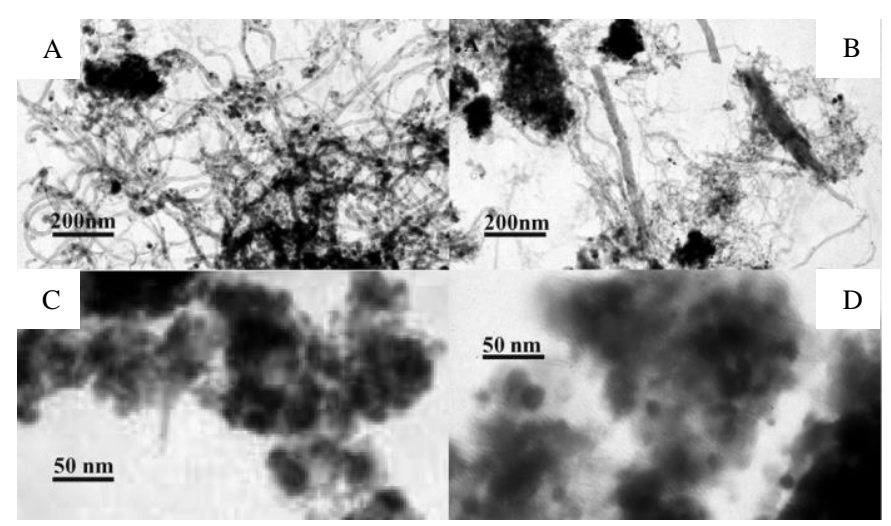

Figure.27 TEM images of Ni-Co catalysts after $250 \mathrm{~h}$ tests. (A) $0.18 \mathrm{Ni0} .16 \mathrm{Co}$; (B) $0.06 \mathrm{Ni0} .09 \mathrm{Co}$; (C) $0.04 \mathrm{Ni} 0.05 \mathrm{Co}$; (D) $0.02 \mathrm{Ni} 0.03 \mathrm{Co}$

\section{Conclusions and Prospects}


In this problem report, thermodynamic calculations and kinetic approaches of methane steam reforming and related coke formation have been addressed in details. More concerns about coke on Nibased anode material for SOFC are shown and corresponding solutions are also proposed. Carbon formation on Ni-YSZ anode material for hydrocarbon steam reforming has long been a great challenge for the researchers working in related fields. After decade years of research, significant progress and achievements have been accomplished in predicting the tendency of coke by thermodynamic calculation and studying the mechanism of carbon deposition in different conditions using Ni-YSZ as catalyst for power generation on solid oxide fuel cells. Many typical problems corresponding to catalyst activity or production selectivity can be solved by adjusting catalyst compositions, feed compositions, and reaction conditions. Now researchers are seeking for more paths to decrease the carbon formation during methane steam reforming, like trying new catalyst-synthesis methods or preparing more metal alloying with $\mathrm{Ni}$ and significant progresses have been made yet. There also can be more efforts from the view of optimization the working conditions or microstructures of SOFCs. For example, some recent researches reported [100] that by optimizing the oxygen flux, which can be also regarded as current density of the fuel cell, from the cathode side, carbon formation on the anode side can be consumed or even prevented. However, the detailed mechanism is still under discussion. As more studies will be done on varieties of materials, we will get a much more stable-running fuel cell system for a long service time without carbon formation deactivation as a concern.

\section{References}

1. Kalamaras, C.M. and A.M. Efstathiou. Hydrogen production technologies: current state and future developments. in Conference Papers in Science. 2013. Hindawi Publishing Corporation.

2. Iulianelli, A., et al., Advances on methane steam reforming to produce hydrogen through membrane reactors technology: A review. Catalysis Reviews-Science and Engineering, 2016. 58(1): p. 1-35. 
3. Rostrup-Nielsen, J.R., J. Sehested, and J.K. Nørskov, Hydrogen and synthesis gas by steam-and CO 2 reforming. Advances in catalysis, 2002. 47: p. 65-139.

4. Oyama, S.T., et al., Dry reforming of methane has no future for hydrogen production: comparison with steam reforming at high pressure in standard and membrane reactors. international journal of hydrogen energy, 2012. 37(13): p. 10444-10450.

5. Kim, S.-D., et al., Effects of anode and electrolyte microstructures on performance of solid oxide fuel cells. Journal of Power Sources, 2007. 169(2): p. 265-270.

6. Ott, J., et al., A micromechanical model for effective conductivity in granular electrode structures. Acta Mechanica Sinica, 2013. 29(5): p. 682-698.

7. Sammes, N. and Y. Du, Intermediate-temperature SOFC electrolytes. Fuel Cell Technologies: State and Perspectives, 2005: p. 19-34.

8. Noh, H.-S., et al., The potential and challenges of thin-film electrolyte and nanostructured electrode for yttria-stabilized zirconia-base anode-supported solid oxide fuel cells. Journal of Power Sources, 2014. 247: p. 105-111.

9. Laosiripojana, N. and S. Assabumrungrat, Catalytic steam reforming of methane, methanol, and ethanol over Ni/YSZ: the possible use of these fuels in internal reforming SOFC. Journal of Power Sources, 2007. 163(2): p. 943-951.

10. Wincewicz, K.C. and J.S. Cooper, Taxonomies of SOFC material and manufacturing alternatives. Journal of Power Sources, 2005. 140(2): p. 280-296.

11. Assabumrungrat, S., et al., Thermodynamic analysis of carbon formation in a solid oxide fuel cell with a direct internal reformer fuelled by methanol. Journal of Power Sources, 2005. 139(1-2): p. $55-60$.

12. Da Silva, A.L., C. de Fraga Malfatti, and I.L. Müller, Thermodynamic analysis of ethanol steam reforming using Gibbs energy minimization method: a detailed study of the conditions of carbon deposition. international journal of hydrogen energy, 2009. 34(10): p. 4321-4330. 
13. Sumi, H., et al., Effect of carbon deposition by carbon monoxide disproportionation on electrochemical characteristics at low temperature operation for solid oxide fuel cells. Journal of Power Sources, 2011. 196(10): p. 4451-4457.

14. Chen, D., et al., Synthesis of carbon nanofibers: effects of Ni crystal size during methane decomposition. Journal of Catalysis, 2005. 229(1): p. 82-96.

15. Mahato, N., et al., Progress in material selection for solid oxide fuel cell technology: a review. Progress in Materials Science, 2015. 72: p. 141-337.

16. Lee, W.Y., J. Hanna, and A.F. Ghoniem, On the predictions of carbon deposition on the nickel anode of a SOFC and its impact on open-circuit conditions. Journal of The Electrochemical Society, 2013. 160(2): p. F94-F105.

17. Argyle, M.D. and C.H. Bartholomew, Heterogeneous catalyst deactivation and regeneration: $a$ review. Catalysts, 2015. 5(1): p. 145-269.

18. Arora, S. and R. Prasad, An overview on dry reforming of methane: strategies to reduce carbonaceous deactivation of catalysts. RSC Advances, 2016. 6(110): p. 108668-108688.

19. Bartholomew, C.H., Carbon deposition in steam reforming and methanation. Catalysis Reviews Science and Engineering, 1982. 24(1): p. 67-112.

20. Tabrizi, F.F., S.A.H.S. Mousavi, and H. Atashi, Thermodynamic analysis of steam reforming of methane with statistical approaches. Energy Conversion and Management, 2015. 103: p. 10651077.

21. Bauman, Y.I., et al., Synthesis of bimodal carbon structures via metal dusting of Ni-based alloys. Materials Letters, 2017. 201: p. 70-73.

22. Cullinan, M.A. and M.L. Culpepper, Control of carbon nanotube geometry via tunable process parameters. Applied Physics Letters, 2008. 93(10): p. 103106.

23. Singh, D., et al., Carbon deposition in an SOFC fueled by tar-laden biomass gas: a thermodynamic analysis. Journal of power sources, 2005. 142(1-2): p. 194-199. 
24. Chen, D., et al., Deactivation during carbon dioxide reforming of methane over Ni catalyst: microkinetic analysis. Chemical Engineering Science, 2001. 56(4): p. 1371-1379.

25. Oliveira, E.L., C.A. Grande, and A.E. Rodrigues, Steam methane reforming in a Ni/Al2O3 catalyst: kinetics and diffusional limitations in extrudates. The Canadian Journal of Chemical Engineering, 2009. 87(6): p. 945-956.

26. Soliman, M., et al., Intrinsic kinetics of nickel/calcium aluminate catalyst for methane steam reforming. Journal of Chemical Technology and Biotechnology, 1992. 55(2): p. 131-138.

27. Schädel, B.T., M. Duisberg, and O. Deutschmann, Steam reforming of methane, ethane, propane, butane, and natural gas over a rhodium-based catalyst. Catalysis today, 2009. 142(1-2): p. 42-51.

28. De Souza, T.L., et al., Thermodynamic analysis of autothermal reforming of methane via entropy maximization: Hydrogen production. international journal of hydrogen energy, 2014. 39(16): p. 8257-8270.

29. Wang, F., et al., Thermal and chemical reaction performance analyses of steam methane reforming in porous media solar thermochemical reactor. international journal of hydrogen energy, 2014. 39(2): p. 718-730.

30. Chen, W.-H., et al., Thermodynamic analysis of hydrogen production from methane via autothermal reforming and partial oxidation followed by water gas shift reaction. international journal of hydrogen energy, 2010. 35(21): p. 11787-11797.

31. Li, Y., et al., Thermodynamic analysis of autothermal steam and CO2 reforming of methane. International Journal of Hydrogen Energy, 2008. 33(10): p. 2507-2514.

32. Demidov, D., I. Mishin, and M. Mikhailov, Gibbs free energy minimization as a way to optimize the combined steam and carbon dioxide reforming of methane. international journal of hydrogen energy, 2011.36(10): p. 5941-5950.

33. Özkara-Aydınoğlu, Ş., Thermodynamic equilibrium analysis of combined carbon dioxide reforming with steam reforming of methane to synthesis gas. international journal of hydrogen energy, 2010. 35(23): p. 12821-12828. 
34. Wang, X., et al., Thermodynamic analysis of propane dry and steam reforming for synthesis gas or hydrogen production. International Journal of hydrogen energy, 2010. 35(23): p. 12800-12807.

35. Silva, J.M., M. Soria, and L.M. Madeira, Thermodynamic analysis of Glycerol Steam Reforming for hydrogen production with in situ hydrogen and carbon dioxide separation. Journal of Power Sources, 2015. 273: p. 423-430.

36. Simakov, D.S., et al., Solar thermal catalytic reforming of natural gas: a review on chemistry, catalysis and system design. Catalysis Science \& Technology, 2015. 5(4): p. 1991-2016.

37. Annesini, M., V. Piemonte, and L. Turchetti, Carbon formation in the steam reforming process: a thermodynamic analysis based on the elemental composition. Chemical Engineering, 2007. 11.

38. Green, D.W. and R.H. Perry, Perry's Chemical Engineers' Handbook/edición Don W. Green y Robert H. Perry. 1973.

39. Challiwala, M., et al., A combined thermo-kinetic analysis of various methane reforming technologies: comparison with dry reforming. Journal of CO2 Utilization, 2017. 17: p. 99-111.

40. Nikoo, M.K. and N. Amin, Thermodynamic analysis of carbon dioxide reforming of methane in view of solid carbon formation. Fuel Processing Technology, 2011. 92(3): p. 678-691.

41. Seo, Y.-S., A. Shirley, and S. Kolaczkowski, Evaluation of thermodynamically favourable operating conditions for production of hydrogen in three different reforming technologies. Journal of Power sources, 2002. 108(1): p. 213-225.

42. Adhikari, S., et al., A thermodynamic analysis of hydrogen production by steam reforming of glycerol. International Journal of Hydrogen Energy, 2007. 32(14): p. 2875-2880.

43. Takeguchi, T., et al., Study on steam reforming of CH4 and C2 hydrocarbons and carbon deposition on Ni-YSZ cermets. Journal of Power Sources, 2002. 112(2): p. 588-595.

44. Bengaard, H.S., et al., Steam reforming and graphite formation on Ni catalysts. Journal of Catalysis, 2002. 209(2): p. 365-384.

45. Girona, K., et al., Carbon deposition in $\mathrm{CH} 4 / \mathrm{CO} 2$ operated SOFC: simulation and experimentation studies. Journal of Power Sources, 2012. 210: p. 381-391. 
46. Klein, J.-M., et al., Modeling of a SOFC fuelled by methane: from direct internal reforming to gradual internal reforming. Chemical Engineering Science, 2007. 62(6): p. 1636-1649.

47. Nikooyeh, K., A.A. Jeje, and J.M. Hill, 3D modeling of anode-supported planar SOFC with internal reforming of methane. Journal of Power Sources, 2007. 171(2): p. 601-609.

48. Hohenberg, P., Phys. Rev. 136(1964) B 864; W. Kohn. L. J. Sham, Phys. Rev., 1965. 140: p. A 1133.

49. Parr, R., RG Parr, Ann. Rev. Phys. Chem. 34, 631 (1983). Ann. Rev. Phys. Chem., 1983. 34: p. 631.

50. Jarrah, N.A., J.G. van Ommen, and L. Lefferts, Mechanistic aspects of the formation of carbonnanofibers on the surface of Ni foam: a new microstructured catalyst support. Journal of Catalysis, 2006. 239(2): p. 460-469.

51. Temkin, M., The kinetics of some industrial heterogeneous catalytic reactions, in Advances in Catalysis. 1979, Elsevier. p. 173-291.

52. Rostrup-Nielsen, J.R., Catalytic steam reforming, in Catalysis. 1984, Springer. p. 1-117.

53. $\mathrm{Xu}, \mathrm{J}$. and G.F. Froment, Methane steam reforming, methanation and water-gas shift: I. Intrinsic kinetics. AIChE journal, 1989. 35(1): p. 88-96.

54. $\mathrm{Xu}$, J. and G.F. Froment, Methane steam reforming: II. Diffusional limitations and reactor simulation. AIChE Journal, 1989. 35(1): p. 97-103.

55. Froment, G.F., K.B. Bischoff, and J. De Wilde, Chemical Reactor-Analysis and Design. 2011.

56. Holstein, W.L., The roles of ordinary and soret diffusion in the metal-catalyzed formation of filamentous carbon. Journal of catalysis, 1995. 152(1): p. 42-51.

57. Iulianelli, A., et al., Advances on methane steam reforming to produce hydrogen through membrane reactors technology: A review. Catalysis Reviews, 2016. 58(1): p. 1-35.

58. Hecht, E.S., et al., Methane reforming kinetics within a Ni-YSZ SOFC anode support. Applied Catalysis A: General, 2005. 295(1): p. 40-51.

59. Kee, R.J., M.E. Coltrin, and P. Glarborg, Chemically reacting flow: theory and practice. 2005: John Wiley \& Sons. 
60. Jones, G., et al., First principles calculations and experimental insight into methane steam reforming over transition metal catalysts. Journal of Catalysis, 2008. 259(1): p. 147-160.

61. Snoeck, J.-W., G. Froment, and M. Fowles, Filamentous carbon formation and gasification: thermodynamics, driving force, nucleation, and steady-state growth. Journal of Catalysis, 1997. 169(1): p. 240-249.

62. Grabke, H.-J., E.M. Müller, and G. Konczos, Kinetics of carburization and decarburization of iron and iron-10\% nickel in CH4 H2 mixtures. Scripta Metallurgica, 1980. 14(1): p. 159-162.

63. Grabke, H. and E. Martin, Kinetics and Thermodynamics of Carburization and Decarburization of Alpha-Fe in Methane-H Mixtures. Arch Eisenhuttenwesen, 1973. 44(11): p. 837-842.

64. Grabke, H., Evidence on the surface concentration of carbon on gamma iron from the kinetics of the carburization in CH 4- H 2. Metallurgical Transactions, 1970. 1(10): p. 2972-2975.

65. Amin, A.M., E. Croiset, and W. Epling, Review of methane catalytic cracking for hydrogen production. International Journal of Hydrogen Energy, 2011. 36(4): p. 2904-2935.

66. Fan, P., et al., Experimental study of the carbon deposition from CH4 onto the Ni/YSZ anode of SOFCs. Fuel Cells, 2016. 16(2): p. 235-243.

67. Snoeck, J.-W., G. Froment, and M. Fowles, Steam/CO2 reforming of methane. Carbon filament formation by the Boudouard reaction and gasification by $\mathrm{CO} 2$, by $\mathrm{H} 2$, and by steam: kinetic study. Industrial \& engineering chemistry research, 2002. 41(17): p. 4252-4265.

68. McIntosh, S. and R.J. Gorte, Direct hydrocarbon solid oxide fuel cells. Chemical reviews, 2004. 104(10): p. 4845-4866.

69. Toebes, M.L., et al., Impact of the structure and reactivity of nickel particles on the catalytic growth of carbon nanofibers. Catalysis today, 2002. 76(1): p. 33-42.

70. Rakass, S., et al., Steam reforming of methane over unsupported nickel catalysts. Journal of Power sources, 2006. 158(1): p. 485-496. 
71. Dewoolkar, K.D. and P.D. Vaidya, Improved hydrogen production by sorption-enhanced steam methane reforming over hydrotalcite-and calcium-based hybrid materials. Energy \& Fuels, 2015. 29(6): p. 3870-3878.

72. Choudhary, V., K. Mondal, and T. Choudhary, Partial oxidation of methane to syngas with or without simultaneous steam or CO 2 reforming over a high-temperature stable-NiCoMgCeO $x$ supported on zirconia-hafnia catalyst. Applied Catalysis A: General, 2006. 306: p. 45-50.

73. Trovarelli, A., Catalytic properties of ceria and CeO2-containing materials. Catalysis Reviews, 1996. 38(4): p. 439-520.

74. Nakagawa, N., H. Sagara, and K. Kato, Catalytic activity of Ni-YSZ-CeO2 anode for the steam reforming of methane in a direct internal-reforming solid oxide fuel cell. Journal of power sources, 2001. 92(1-2): p. 88-94.

75. Laosiripojana, N., W. Sangtongkitcharoen, and S. Assabumrungrat, Catalytic steam reforming of ethane and propane over CeO2-doped Ni/Al2O3 at SOFC temperature: Improvement of resistance toward carbon formation by the redox property of doping CeO2. Fuel, 2006. 85(3): p. 323-332.

76. Zhang, C., et al., Synthesis of stable Ni-CeO2 catalysts via ball-milling for ethanol steam reforming. Catalysis Today, 2014. 233: p. 53-60.

77. Guo, J., et al., The reactivity of surface active carbonaceous species with CO2 and its role on hydrocarbon conversion reactions. Journal of Molecular Catalysis A: Chemical, 2010. 316(1-2): p. 1-7.

78. Kang, K.-M., et al., Catalytic test of supported Ni catalysts with core/shell structure for dry reforming of methane. Fuel Processing Technology, 2011. 92(6): p. 1236-1243.

79. Lemonidou, A.A. and I.A. Vasalos, Carbon dioxide reforming of methane over $5 \mathrm{wt}$ \% $\mathrm{Ni} / \mathrm{CaO}$ Al2O3 catalyst. Applied Catalysis A: General, 2002. 228(1-2): p. 227-235.

80. Nagaraja, B.M., et al., The effect of potassium on the activity and stability of $\mathrm{Ni}-\mathrm{MgO}-\mathrm{ZrO} 2$ catalysts for the dry reforming of methane to give synthesis gas. Catalysis today, 2011. 178(1): p. 132-136. 
81. Carrero, A., J. Calles, and A. Vizcaíno, Effect of $\mathrm{Mg}$ and Ca addition on coke deposition over Cu$\mathrm{Ni} / \mathrm{SiO} 2$ catalysts for ethanol steam reforming. Chemical Engineering Journal, 2010. 163(3): p. 395-402.

82. Zhang, J., H. Wang, and A.K. Dalai, Effects of metal content on activity and stability of Ni-Co bimetallic catalysts for $\mathrm{CO} 2$ reforming of $\mathrm{CH}$ 4. Applied Catalysis A: General, 2008. 339(2): p. 121-129.

83. Chen, L., Q. Zhu, and R. Wu, Effect of Co-Ni ratio on the activity and stability of Co-Ni bimetallic aerogel catalyst for methane Oxy-CO 2 reforming. international journal of hydrogen energy, 2011. 36(3): p. 2128-2136.

84. Li, X., et al., Ni-Co bimetallic catalyst for $\mathrm{CH} 4$ reforming with $\mathrm{CO} 2$. Frontiers of Chemical Engineering in China, 2010. 4(4): p. 476-480.

85. Djinović, P., et al., Influence of active metal loading and oxygen mobility on coke-free dry reforming of Ni-Co bimetallic catalysts. Applied Catalysis B: Environmental, 2012. 125: p. 259270.

86. Luisetto, I., S. Tuti, and E. Di Bartolomeo, Co and Ni supported on CeO 2 as selective bimetallic catalyst for dry reforming of methane. international journal of hydrogen energy, 2012. 37(21): p. 15992-15999.

87. Takanabe, K., et al., Titania-supported cobalt and nickel bimetallic catalysts for carbon dioxide reforming of methane. Journal of Catalysis, 2005. 232(2): p. 268-275.

88. Ay, H. and D. Üner, Dry reforming of methane over CeO 2 supported Ni, Co and Ni-Co catalysts. Applied Catalysis B: Environmental, 2015. 179: p. 128-138.

89. San-José-Alonso, D., et al., $\mathrm{Ni}$, Co and bimetallic Ni-Co catalysts for the dry reforming of methane. Applied Catalysis A: General, 2009. 371(1): p. 54-59.

90. Resini, C., et al., Yttria-stabilized zirconia (YSZ) supported Ni-Co alloys (precursor of SOFC anodes) as catalysts for the steam reforming of ethanol. International Journal of Hydrogen Energy, 2008. 33(14): p. 3728-3735. 
91. San-José-Alonso, D., et al., Ni, Co and bimetallic Ni-Co catalysts for the dry reforming of methane. Applied Catalysis A: General, 2009. 371(1-2): p. 54-59.

92. Kim, H., et al., Cu-Ni cermet anodes for direct oxidation of methane in solid-oxide fuel cells. Journal of the Electrochemical Society, 2002. 149(3): p. A247-A250.

93. Park, E.W., et al., Fabrication and characterization of $\mathrm{Cu}-\mathrm{Ni}-\mathrm{YSZ}$ SOFC anodes for direct use of methane via Cu-electroplating. international journal of hydrogen energy, 2009. 34(13): p. 55375545.

94. Nikolla, E., J. Schwank, and S. Linic, Promotion of the long-term stability of reforming Ni catalysts by surface alloying. Journal of catalysis, 2007. 250(1): p. 85-93.

95. Nikolla, E., J.W. Schwank, and S. Linic, Hydrocarbon steam reforming on Ni alloys at solid oxide fuel cell operating conditions. Catalysis Today, 2008. 136(3-4): p. 243-248.

96. Nikolla, E., J. Schwank, and S. Linic, Direct electrochemical oxidation of hydrocarbon fuels on SOFCs: improved carbon tolerance of Ni alloy anodes. Journal of the Electrochemical Society, 2009. 156(11): p. B1312-B1316.

97. Jeong, J.H., et al., Ru-doped Ni catalysts effective for the steam reforming of methane without the pre-reduction treatment with H 2. Applied Catalysis A: General, 2006. 302(2): p. 151-156.

98. Takeguchi, T., et al., Effect of precious metal addition to Ni-YSZ cermet on reforming of CH4 and electrochemical activity as SOFC anode. Catalysis today, 2003. 84(3-4): p. 217-222.

99. Christensen, K.O., et al., Effect of supports and Ni crystal size on carbon formation and sintering during steam methane reforming. Applied Catalysis A: General, 2006. 314(1): p. 9-22.

100. Xiao, J., et al., Deactivation of nickel-based anode in solid oxide fuel cells operated on carboncontaining fuels. Journal of Power Sources, 2014. 268: p. 508-516. 